Review

\title{
TROPICAL AGRICULTURE AND GLOBAL WARMING: IMPACTS AND MITIGATION OPTIONS
}

\author{
Carlos Eduardo P. Cerri ${ }^{1 *}$; Gerd Sparovek ${ }^{1}$; Martial Bernoux ${ }^{2}$; Willian E. Easterling ${ }^{3}$; Jerry \\ M. Melillo ${ }^{4}$; Carlos Clemente Cerri ${ }^{5}$ \\ ${ }^{1}$ USP/ESALQ - Depto. de Ciência do Solo. C.P. 09 - 13418-900 - Piracicaba, SP - Brasil. \\ ${ }_{3}^{2}$ IRD. Institut de Recherche pour le Développement. BP 64501 - 34394 - Montpellier, France. \\ ${ }^{3}$ Pennsylvania State University. Penn State Institutes of the Environment - 16802 - University Park, PA - USA. \\ ${ }_{5}^{4}$ Marine Biological Laboratory. The Ecosystems Center - 02543 - Woods Hole, MA -USA. \\ ${ }^{5}$ USP/CENA - Laboratório de Biogeoquímica Ambiental. C.P. 96 - 13400-970 - Piracicaba, SP - Brasil. \\ *Corresponding author <cepcerri@cena.usp.br>
}

\begin{abstract}
The intensive land use invariably has several negative effects on the environment and crop production if conservative practices are not adopted. Reduction in soil organic matter (SOM) quantity means gas emission (mainly $\mathrm{CO}_{2}, \mathrm{CH}_{4}, \mathrm{~N}_{2} \mathrm{O}$ ) to the atmosphere and increased global warming. Soil sustainability is also affected, since remaining SOM quality changes. Alterations can be verified, for example, by soil desegregation and changes in structure. The consequences are erosion, reduction in nutrient availability for the plants and lower water retention capacity. These and other factors reflect negatively on crop productivity and sustainability of the soil-plant-atmosphere system. Conversely, adoption of "best management practices", such as conservation tillage, can partly reverse the process - they are aimed at increasing the input of organic matter to the soil and/or decreasing the rates at which soil organic matter decomposes.
\end{abstract}

Key words: Brazil, climate change, greenhouse effect, soil organic matter, management practices

\section{AGRICULTURA TROPICAL E AQUECIMENTO GLOBAL: IMPACTOS E OPÇÕES DE MITIGAÇÃO}

\begin{abstract}
RESUMO: O uso intensivo da terra invariavelmente causa efeitos negativos ao ambiente e produção agrícola se práticas conservativas não forem adotadas. Redução na quantidade de matéria orgânica do solo significa emissão de gases (principalmente $\mathrm{CO}_{2}, \mathrm{CH}_{4}, \mathrm{~N}_{2} \mathrm{O}$ ) para a atmosfera e aumento do aquecimento global. A sustentabilidade do solo é também afetada, uma vez que a qualidade da matéria orgânica remanescente muda. Alterações podem ser verificadas, por exemplo, pela desagregação do solo e mudança na sua estrutura. As consequências são erosão, redução na disponibilidade de nutrientes para as plantas e baixa capacidade de retenção de água no solo. Estes e outros fatores refletem negativamente na produtivade das culturas e sustentabilidade do sistema solo-planta-atmosfera. Ao contrário, a adoção de boas práticas de manejo, tal como o sistema plantio direto, pode parcialmente reverter o processo, uma vez que objetiva o aumento das entradas de material orgânico no solo e/ou diminuição das taxas de decomposição da matéria orgânica do solo.

Palavras-chave: Brasil, mudanças climáticas, efeito estufa, matéria orgânica do solo, boas práticas de manejo
\end{abstract}

\section{INTRODUCTION}

The need for food for an increasing population often threatens natural resources as people strive to obtain the most out of land already in production or push into virgin territory for new agricultural land (FAO, 2005). The damage is increasingly evident: erosion of arable lands, salinity, desertification, and urban spread; water shortages; deforestation; and threats to biodiversity (Foley et al., 2005). The situation is likely to be further worsened by the potential impacts of global warming and climate change on the growing conditions of crops (IIASA, 2001; IPCC, 2003).

Ruddiman (2005) reported that about eight thousand years ago, humans began to modify the environment and greenhouse gas concentrations in the atmosphere started to increase. However, more land was converted to cropland since 1945 than in the eighteenth and nineteenth centuries combined, and now approximately one quarter (24\%) of Earth's terrestrial 
surface has been transformed into cultivated systems. Over this recent period, human population increased exponentially and, therefore, has changed ecosystems more rapidly and extensively than in any comparable period of time in human history, largely to meet rapidly growing demands for food, fresh water, timber, fiber, and fuel (Millennium Ecosystem Assessment, 2005)

Nowadays, the adverse consequences of global warming, expressed as global climate change, are among the main actual environmental concerns faced by human beings (Kerr, 2005). From the scientific point of view, global climatic changes are caused by natural and anthropogenic radiative forcings (IPCC, 2001). Positive radiative forcing agents like the greenhouse gases (GHG), the sun and the volcanic eruptions, increase atmospheric temperature, while negative radiative forcing agents (aerosols, clouds and others) cool the terrestrial surface (Hansen et al., 2002). Radiative forcing, expressed as $\mathrm{W} \mathrm{m}^{-2}$, unbalances the incident and emergent solar energy on the Earth. Climate adjusts in response to this energetic disturbance and causes the so called global climate changes (Polwson, 2005).

According to the latest calculations of Hansen et al. (2005), the emerging energy is $0.85 \pm 0.15 \mathrm{~W}$ $\mathrm{m}^{-2}$ smaller than the incident. This energetic difference already caused a global temperature increase of about $0.6^{\circ} \mathrm{C}$ during the period from 1880 to 2003 . The authors also mentioned that the greatest radiative forcing agents are the $\mathrm{GHG}\left(\mathrm{CO}_{2}, \mathrm{CH}_{4}, \mathrm{~N}_{2} \mathrm{O}\right.$ and $\left.\mathrm{CFC}\right)$, responsible for a total of $2.75 \mathrm{~W} \mathrm{~m}^{-2}$ added to the level of 1880 .

Recent National Communications on greenhouse gas (GHG; mainly $\mathrm{CO}_{2}, \mathrm{CH}_{4}, \mathrm{~N}_{2} \mathrm{O}$ ) emissions indicate that in general GHG emitted in the tropics are mainly related to deforestation and agricultural intensification, while in temperate regions GHG comes from the combustion of fossil fuel in the transportation and industry sectors (UNFCCC, 2006). For instance, fossil fuel burning and cement production are globally the major sources, responsible for $66 \%$ of total GHG emitted to the atmosphere. Agriculture (20\%) and land use change (14\%) complete total anthropogenic emissions (IPCC, 2001).

The quantification of GHG contributions due to fossil fuel burning is more exact, since the quantities of petroleum, charcoal and natural gas extracted and consumed per year in the world are well known (Overpeck \& Cole, 2006). The contribution of agriculture and land use changes are more difficult to be estimated, since the sources are diffuse and the systems more complex (Gregory et al., 2005).
In Brazil the proportion between the contributions of GHG from fossil fuel burning versus agriculture and land use is different compared to the global pattern. Fossil fuel burning is less important (Brasil, 2004), while land use change and agriculture respond for more than two thirds of total emissions. If the gases derived from deforestation process are considered (Fearnside, 2006), Brazil rises from the $17^{\text {th }}$ to the $5^{\text {th }}$ position in the ranking of countries with the greatest emission rates.

Despite the great efforts of governments in tropical areas, illegal deforestation has occurred over large areas (INPE, 2006). Although the cleared land makes more area available for food production, it has various negative impacts (Fearnside, 2006). Firstly, it exacerbates global climate change, which has a negative feedback in the global food production (Knorr et al., 2005). Food production can suffer from climate change impacts such as alteration in solar radiation period and extreme weather events (IPCC, 2001; Overpeck \& Cole, 2006). Secondly, the illegal and random deforestation reduces crop production by jeopardizing environmental services such as crop pollination, genetic resources, clean air and water supplies (Foley et al., 2005), soil fertility and erosion (Bertol et al., 2005), pests and pathogen controls that help to maintain crop production (Ghini \& Morandi, 2006).

The main reason for these facts is that temperate zones already achieved their needs on calories and yields, and the population reached steady state equilibrium. On the other hand, tropical areas are the ones with more human population, demanding more food. Moreover, crop yields in the tropics are reduced, mainly due to lack of good practice adoption and poor technological resources. In order to compensate these adverse conditions, tropical native ecosystems have been converted (Fearnside, 2006). Mainly in the past ten years, part of the converted areas are been used to produce food for export and consequently improving the GDP.

In addition to food, tropical regions are also producing fibers and bio-fuels, such as ethanol and biodiesel. At the beginning, bio-fuels were generated to help developing countries to achieve their self sustainability on fuel consumption. However, nowadays bio-fuels produced in tropical areas are being negotiated to be used as off-set of fossil fuel in Annex I countries, as a complementary action used to meet their targets on GHG emission reductions, proposed by the Kyoto Protocol (UNFCCC, 2006).

\section{$\mathrm{CO}_{2}$ emission by agricultural land in Brazil}

Concerns about global warming and increasing atmospheric greenhouse gases concentrations $\left(\mathrm{CO}_{2}\right.$, 
$\mathrm{CH}_{4}$, and $\mathrm{N}_{2} \mathrm{O}$ ) have led to questions on the role of soils as a source or sink of carbon (Houghton, 2003). Excluding carbonated rocks, soils constitute the largest surface carbon pool, approximately 1500 Gt, equivalent to almost three times the quantity stored in the terrestrial biomass and twice the amount stored in the atmosphere (IPCC, 2003).

Therefore, any modification of land use or land management can induce changes in soil carbon stocks, even in agricultural systems in which carbon is perceived to be in a steady state (Six et al., 2002; Lal, 2006). For the Brazilian territory, the procedures adopted to estimate $\mathrm{CO}_{2}$ emission from agricultural land are described in Bernoux et al. (2001; 2002).

Briefly, soil organic $\mathrm{C}$ stocks to a depth of 30 $\mathrm{cm}$ were estimated for Brazil on the basis of a map of different soil-vegetation associations combined with results from a soil database. The soil-vegetation map was derived by combination of soil (EMBRAPA, 1981) and vegetation (IBGE, 1988) maps at the 1:5,000,000 scale. The original soil and vegetation classifications were simplified to six soil classes (from 2698 map units divided into 69 soil types) and 15 vegetation categories (from 2021 map units divided into 94 vegetation types) on the basis of criteria recommended by IPCC (1997). The soil-vegetation map comprised 75 categories in 21,111 map units. Mean representative $C$ stocks of the map categories were calculated using a soil profile database (Bernoux et al., 2002) containing information on $\mathrm{C}$ concentration, bulk density, soil type and native vegetation. Approximately 2694 soil profiles were used to obtain the range of 1.5 to $41.8 \mathrm{~kg} \mathrm{C} \mathrm{m}^{-2}$ for the mean representative $\mathrm{C}$ stocks (Figure 1). In total, Bernoux et al. (2002) estimated that about $36.4 \pm$ 3.4 Pg C was stored in the 0-30 cm layer of Brazil.

Using the map of the Brazilian soil C stocks for the 0-30 cm layer, Bernoux et al. (2001) calculated the first approximation of $\mathrm{CO}_{2}$ fluxes from soils in Brazil for the 20 year periods of 1970-1990 and 19751995. The methodology employed was an adaptation of the approach proposed by the IPCC in "Revised 1996 guidelines for national greenhouse gas inventories", which is based on the variation in soil C stocks as a function of change in land-use. They showed that the annual fluxes for Brazil indicate a net emission of $\mathrm{CO}_{2}$ to the atmosphere, which decreased from $93.3 \mathrm{Tg}$ $\mathrm{CO}_{2}$ for the period 1970-1990 to $46.4 \mathrm{Tg} \mathrm{CO}_{2}$ (or 12.65 $\mathrm{Tg}$ C) for the period 1975-1995. This important change is associated with the rapid changes of land use in Brazil (Bernoux et al., 2001).

Impact of climate change on the tropical agriculture Global climate changes caused by increased greenhouse gas emissions to the atmosphere from an-

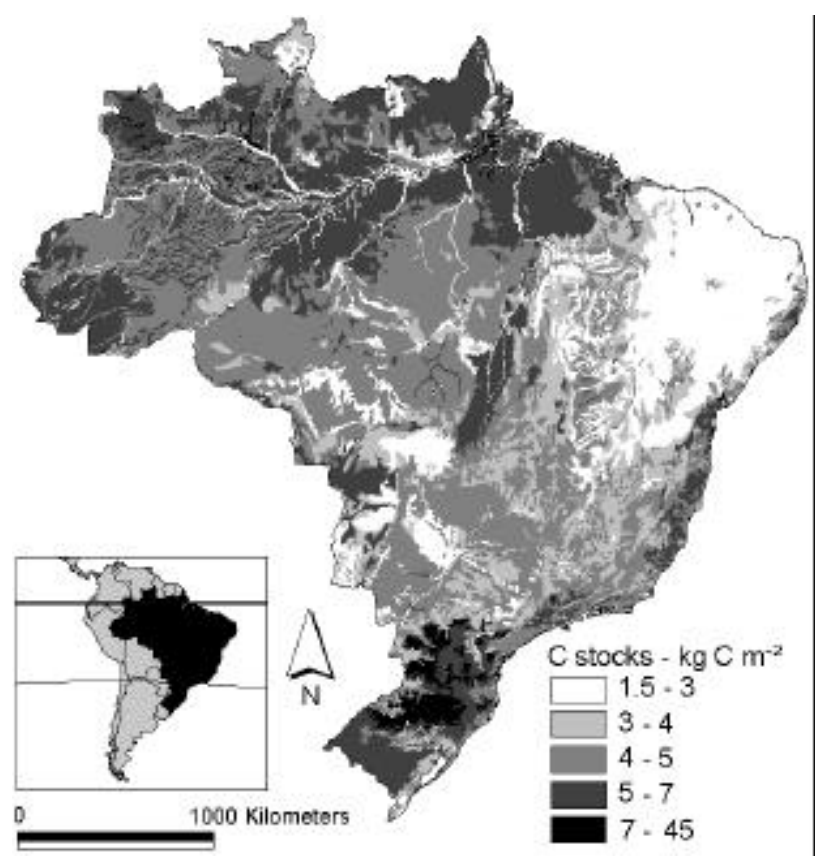

Figure 1 - Map of soil carbon stocks $(0-30 \mathrm{~cm})$ in the soils of Brazil. Adapted from Bernoux et al. (2002).

thropogenic activities have direct influence on natural and agrosystem functioning (Lal, 2002). Modifications in hydrologic regimes and atmosphere temperature due to anthropogenic greenhouse effect provoke variations in plant productivity and therefore, affect food production (IPCC, 2003).

Crop simulation models, driven by future climate scenarios from global circulation models, suggest that the reduction in agricultural production would be more severe in tropical regions (IPCC, 2001), where there is still a shortage of food production.

No clear picture has emerged on the regional consequences of climate change for agricultural production. However, uncertainties are beginning to narrow on some general research findings. The Third Assessment Report (TAR) of the Intergovernmental Panel on Climate Change (IPCC), summarized by Easterling \& Apps (2005), reported that models simulate the capacity of temperate crops to absorb 2-3 degrees C of warming before showing signs of stress. Crops grown in the tropics, wheat especially, exhibit immediate yield decline with even the slightest warming (Figure 2) because they are currently grown under conditions close to maximum temperature tolerances-even a little warming sends them over the edge. Developing countries everywhere will strain to maintain food security while preserving ecosystem services as they meet the challenges of climate change.

Brazil, located almost entirely in the tropical zone, is not an exception to this rule, and therefore, is 


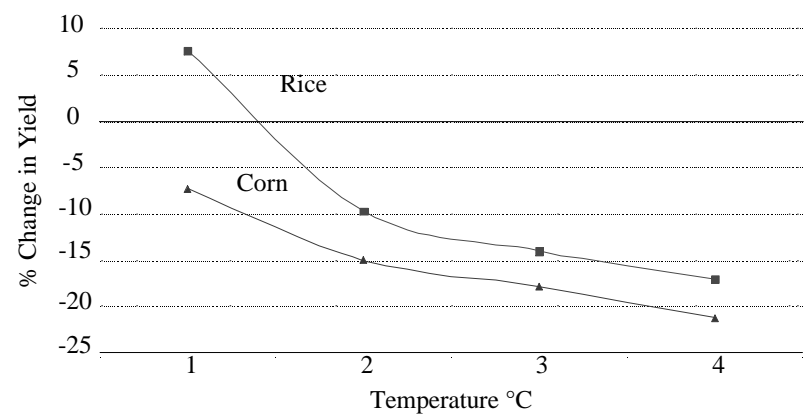

Figure 2 - Corn and rice yields versus temperature increase in the tropics averaged across 13 crop modeling studies. All studies assumed a positive change in precipitation. $\mathrm{CO}_{2}$ direct effects were included in all studies. Adapted form Easterling \& Apps (2005).

susceptible to reductions in agricultural and cattle ranching production. Moreover, agriculture comprises the largest single sector of the Brazilian economy, representing 29\% of the Gross Domestic Product (GDP) in 2002 , and about $47.5 \%$ of the Brazilian exports in 2003. Therefore, understanding the possible impacts of climate change on the Brazilian agriculture is a key point for governmental decision-makers, in order to avoid jeopardizing domestic food production and agricultural exports.

Research about the impacts of climate change on Brazilian agriculture is scanty and has focused mainly only on grain production (Siqueira et al., 1994; 2001). Simulations of grain production are usually done by coupling a crop growth model with a climate change scenario and projected increases in $\mathrm{CO}_{2}$ from a future emission scenario, using historical climate data and current $\mathrm{CO}_{2}$ levels as a base scenario.

Siqueira et al. (1994; 2001) presented results on wheat (Triticum vulgare Vill), maize (Zea mays L.) and soybean (Glycine max L. Merr) production simulations with the crop growth model CERES and SOYGRO for 13 Brazilian situations under climate change scenarios generated by GISS (Goddard Institute for Space Studies), GFDL (Geophysical Fluid Dynamic Laboratory) and UKMO (United Kingdom Meteorological Office) GCMs run with 330 and 555 ppm $\mathrm{CO}_{2}$.

Siqueira et al. (2001) reported that simulations show an increase in the mean air temperature between 3 to $5^{\circ} \mathrm{C}$ and an increase of about $11 \%$ in the mean precipitation for the Center-South region throughout the year 2050. This scenario would cause a reduction of 30 and $16 \%$ of the wheat and corn productions, respectively; and an increase of about $21 \%$ in the soybean production. These figures correspond to a reduction of 1 million tonnes of wheat and 2.8 million tonnes of corn and an increase of 3.5 million tonnes of soy- bean. The major problems resultant from additional rainfall are related to higher probability of disease incidences, greater difficulties in cultivation management and higher risks of soil water erosion.

Sivakumar \& Das (2005) pointed out that periodic occurrences of severe El Niño - associated droughts in northeastern Brazil have resulted in occasional famines. Under doubled- $\mathrm{CO}_{2}$ scenarios, yields are projected to fall by 17 to $53 \%$ depending on whether or not direct effects of $\mathrm{CO}_{2}$ are considered.

The effects of the climate change scenarios in the agroclimatic zoning of arabic coffee (Coffea arabica L.) is important in the main plantation areas in Brazil (Silva et al., 2006). The simulations presented by Assad et al. (2004) indicate a reduction of suitable areas greater than $95 \%$ in the states of Goiás, Minas Gerais and São Paulo, and about $75 \%$ for Paraná when the temperature increases in $5.8^{\circ} \mathrm{C}$. In terms of annual crop production, the effects of the high temperatures are negative.

\section{Plant pests}

Plant pests, which include insects, pathogens and weeds, continue to be major constraints to food and agricultural production in both developed and developing countries (Burdon et al., 2006). Crop losses significantly reduce the amount of food available for human and animal consumption, thus contributing directly to food insecurity and poverty (Epstein \& Mills, 2005). They also negatively affect internal and external marketing and trade in agricultural products, reduce farmers' income, and block poverty alleviation (IPCC, 2001).

Global drivers of plant pest problems include intensification of cropping which provides greater host availability for pests, international trade and food aid that increases the movements of plants and often their accompanying pests, migration and tourism that increase movement of people who carry plant materials, and civil conflict and war, that both increase movement of refugees and military personnel and disrupt phytosanitary control systems at borders (FAO, 2005).

Climate change as a driver will have different effects on the various types of pests (Garrett et al., 2006; Ghini \& Morandi, 2006). Based on studies of individual species, climate change may affect: pest developmental rates and numbers of pest generations per year; pest mortality due to cold and freezing during winter months; or host plant susceptibility to pests (Burdon et al., 2006). When two or more species contribute to a pest problem, as with vectored pathogens or pathogens which cause more severe symptoms in the presence of simultaneous insect damage, the effects of climate change could be expressed through any of 
these species (Ghini, 2005; Garrett et al., 2006). Overall temperature increases may influence crop pathogen interactions by speeding up pathogen growth rates, which increases reproductive generations per crop cycle (Ghini \& Morandi, 2006), by decreasing pathogen mortality due to cold winter temperatures, and by effects on the crop itself that leave the crop more vulnerable (FAO, 2005).

As if the inter-relationships between plants, pest organisms, and the existing environment weren't staggeringly complex, the onus of potential global climate change bodes yet further complications of the fragile equation (Ghini, 2005). With a specific focus on major classes of crop pests, Pritchard \& Amthor (2005) suggest that: i) warming may favor most weeds in comparison to crops; ii) rising $\mathrm{CO}_{2}$ also is likely to enhance weed growth relative to crops; iii) being highly adaptable, many weed species can be expected to rapidly and more effectively adapt to increasing stresses such as rising atmospheric ozone and soil salinization; iv) warming trends most likely will also increase abundance, growth rate, and geographic range of many key crop-attacking insect pests; v) warming may, depending on the shifting of precipitation patterns, stimulate microbial pathogens; vi) crop tissue chemistry, including nitrogen and water content as well as inducible defense mechanisms, is likely to evolve as environmental change occurs; vii) on the plus side, rising $\mathrm{CO}_{2}$ may stimulate rhizobia and mycorrhizae and benefit both crop plants and soil dwelling symbionts; and viii) warming (soil) may be beneficial in some regions, but harmful in those regions where optimal soil temperatures already exist.

Control of plant pests still involves substantial use of pesticides, which protect crops and boost productivity but can have severe side effects on human health and the environment (Epstein \& Mills, 2005). The risks for developing countries - where farmers cannot afford less toxic compounds, proper application equipment and appropriate personal protection - are particularly great (FAO, 2005). Genetically modified crops offer a solution to the control of weeds and some pests - and their use has increased as a result (Garrett et al., 2006).

\section{Examples of management practices for greenhouse gas emission reduction and soil carbon sequestra- tion}

\section{Conventional versus no-tillage system}

No-tillage is presumed to be the oldest system of soil management. In some parts of the tropics, Notillage is still practiced as part of slash-and-burn agriculture. After clearing an area of forest, by controlled burning, seed is placed directly into the soil. However, as mankind developed more systematic agricultural systems, cultivation of the soil became an accepted practice as a means of preparing a more suitable environment for plant growth. Paintings in ancient Egyptian tombs portray farmers tilling their fields using a swing-plough and oxen, prior to planting. Indeed, tillage as symbolized by the mouldboard plough became almost synonymous with agriculture (Dick \& Durkalski, 1997). No-tillage can be defined as a crop production system where soil is left undisturbed from harvest to planting except for fertilizer application.

Conversion of native vegetation to cultivated cropland under conventional tillage system has resulted in a significant decline in soil organic matter content (Paustian et al., 2000; Lal, 2002). Farming methods that use mechanical tillage, such as the mouldboard plough for seedbed preparation or discing for weed control, can promote soil C loss by several mechanisms: they disrupt soil aggregates, which protect soil organic matter from decomposition (Karlen \& Cambardella, 1996; Six et al., 1999; Soares et al., 2005), they stimulate short-term microbial activity through enhanced aeration, resulting in increased levels of $\mathrm{CO}_{2}$ and other gases released to the atmosphere (Bayer et al., 2000a; 2000b; Kladivko, 2001), and they mix fresh residues into the soil where conditions for decomposition are often more favourable than on the surface (Karlen \& Cambardella 1996; Plataforma Plantio Direto, 2006). Furthermore, tillage can leave soils more prone to erosion, resulting in further loss of soil C (Bertol et al., 2005; Lal, 2006).

No-tillage practices, however cause less soil disturbance, often resulting in significant accumulation of soil C (Sá et al., 2001; Schuman et al., 2002) and consequent reduction of gas emissions, especially $\mathrm{CO}_{2}$, to the atmosphere (Lal, 1998; Paustian et al., 2000) compared to conventional tillage. There is considerable evidence that the main effect is in the topsoil layers with little overall effect on C storage in deeper layers (Six et al., 2002).

Globally, at present, approximately 63 million ha are under no-tillage systems with USA having the largest area (Lal, 2006). In Brazil the no-tillage system started in the south region (Paraná State) in 1972 as an alternative to the misuse of land causing erosion (Denardin \& Kochhann, 1993). The underlying land management principles that led to the development of no-tillage systems in Brazil were, prevention surface sealing caused by rainfall impact, achievement and maintenance of an open soil structure and reduction of the volume and velocity of surface runoff. Consequently, the no-tillage strategy was based on two essential farm practices: (i) not tilling and (ii) keeping soil covered at all times. This alternative strategy 
quickly expanded to different states and the planted area under no-tillage has since then increased exponentially.

In the early 90's the area covered by the system was 1 million ha increasing 10 times by 1997 . Now, the approximately 20 million ha covered by notillage practice (Febrapdp, 2006) make Brazil the second largest adopter in the world. This expansion is taking place not only as result of the conversion from conventional tillage in the southern region (72\%) but also after clearing natural savannah in centre-west area $(28 \%)$. More recently, due to the high profits, ranchers in the Amazon region are converting old pastures to soybean/millet under no-tillage.

Changes in soil $\mathrm{C}$ stocks under no-tillage have been estimated in earlier studies for temperate and tropical regions. Cambardella \& Elliott (1992) showed an increase of $6.7 \mathrm{t} \mathrm{C} \mathrm{ha}^{-1}$ in the top $20 \mathrm{~cm}$ in a wheatfall rotation system after 20 years of no-tillage in comparison to conventional tillage. Reicosky et al. (1995) reviewed various publications and found that organic matter increased under conservation management systems with rates ranging from 0 to $1.15 \mathrm{t} \mathrm{C} \mathrm{ha}^{-1} \mathrm{yr}^{-1}$, with highest accumulation rates generally occurring in temperate conditions. Lal et al. (1998) calculated a C sequestration rate of 0.1 to $0.5 \mathrm{t} \mathrm{C} \mathrm{ha}^{-1} \mathrm{yr}^{-1}$ in temperate regions. For the tropical west of Nigeria, Lal (1997) observed a $1.33 \mathrm{t} \mathrm{C}^{-1} \mathrm{~h}^{-1}$ increment during 8 years under no-tillage as compared to the conventional tillage of maize, which represents an accumulation rate of $0.17 \mathrm{t} \mathrm{C} \mathrm{ha}^{-1} \mathrm{yr}^{-1}$.

In the tropics, specifically in Brazil, the rate of $\mathrm{C}$ accumulation has been estimated in the two main regions under no-tillage systems (south and centre-west regions). In the southern region Sá (2001) and Sá et al. (2001) estimated a greater sequestration rates of 0.8 t C ha ${ }^{-1} \mathrm{yr}^{-1}$ in the $0-20 \mathrm{~cm}$ layer and $1.0 \mathrm{t} \mathrm{C}^{-1} \mathrm{yr}^{-1}$ in the $0-40 \mathrm{~cm}$ soil depth after 22 years under no-tillage compared to the same period under conventional practice. The authors mentioned that the accumulated $\mathrm{C}$ was generally greater in the coarse $(>20 \mu \mathrm{m})$ than in the fine $(<20 \mu \mathrm{m})$ particle-size-fraction indicating that most of this additional $\mathrm{C}$ is weakly stable.

Bayer et al. (2000a; 2000b) found a C accumulation rate of $1.6 \mathrm{tha}^{-1} \mathrm{yr}^{-1}$ for a 9 year no-tillage system compared with $0.10 \mathrm{t} \mathrm{ha}^{-1} \mathrm{yr}^{-1}$ for the conventional system in the first $30 \mathrm{~cm}$ layer of an Acrisol in the southern part of Brazil. Corazza et al. (1999) reported an additional accumulation of approximately $0.75 \mathrm{t} \mathrm{C} \mathrm{ha}^{-1} \mathrm{yr}^{-1}$ in the $0-40 \mathrm{~cm}$ soil layer due to notillage in the savannah region located in the centralwest (Table 1). Estimates by Amado et al. $(1998 ; 1999)$ indicated an accumulation rate of $2.2 \mathrm{t} \mathrm{ha}^{-1} \mathrm{yr}^{-1}$ of soil organic $\mathrm{C}$ in the first $10 \mathrm{~cm}$ layer. Other studies con- sidering no-till system carried out in the centre-west part of Brazil (Lima et al., 1994; Castro-Filho et al., 1998; Riezebos \& Loerts, 1998; Vasconcellos et al., 1998; Peixoto et al., 1999; Spagnollo et al., 1999; Resck et al., 2000) reported soil C sequestration rates due to no-tillage varying from 0 up to $1.2 \mathrm{t} \mathrm{C} \mathrm{ha}^{-1} \mathrm{yr}^{-1}$ for the $0-10 \mathrm{~cm}$ layer.

Bernoux et al. (2006) reported that most studies of Brazilian soils give rates of carbon storage in the top $40 \mathrm{~cm}$ of the soil of 0.4 to $1.7 \mathrm{t} \mathrm{C} \mathrm{ha}^{-1}$ per year, with the highest rates in the Cerrado region. However, the authors stressed that caution must be taken when analyzing no-till systems in term of carbon sequestration. Comparisons should include changes in trace gas fluxes and should not be limited to a consideration of carbon storage in the soil alone if the full implications for global warming are to be assessed.

As mentioned before, the no-tillage system in Brazil can vary significantly between regions. Therefore, we have used in our calculations of additional soil $\mathrm{C}$ accumulation due to non-tillage a weighted average value of $0.5 \mathrm{t} \mathrm{C} \mathrm{ha}^{-1} \mathrm{yr}^{-1}$ in the first $10 \mathrm{~cm}$ depth. This weighted average was calculated using soil $\mathrm{C}$ sequestration rates for the southern region $(72 \%$ of the notill area) and also for the central-west region (28\% of the cultivated area under no-till system) as data shown in Table 1.

The total area in Brazil under the no-tillage system is about 20 million ha, and the weighted average soil $\mathrm{C}$ accumulation rate due to no-tillage adoption is $0.5 \mathrm{t} \mathrm{C} \mathrm{ha}^{-1} \mathrm{yr}^{-1}$ in the first $10 \mathrm{~cm}$ depth, giving

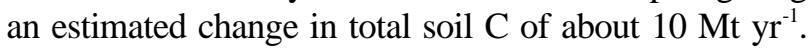
In addition we should include a $\mathrm{C}$ offset due to a significant reduction in fuel consumption (60 to $70 \%)$ in the no-tillage system as compared to the conventional tillage (Plataforma Plantio Direto, 2006).

It is important to mention that there is a lot of controversy regarding whether no-till really does sequester much soil C, especially when the whole soil profile is considered (Smith et al., 1998). Most studies that have looked at the whole profile have shown insignificant soil $\mathrm{C}$ gain. The quantity of residues returned, variations in the practices implemented and perhaps the type of climate are factors likely to influence the outcome. According to Smith et al. (1998) only certain fixed amounts of soil $\mathrm{C}$ can be gained up to a new equilibrium limit, which is reversible if management reverts to conventional tillage.

\section{Burning versus non-burning harvesting sugar cane system}

The sugar cane crop offers one of the most cost-effective renewable energy sources that are readily available in developing countries (Macedo, 1998). It 
Table 1 - Carbon storage rates (accumulation following conversion of a conventional to no-tillage system) in no-tillage systems in Brazil. Expanded from Bernoux et al. (2006).

\begin{tabular}{|c|c|c|c|c|c|c|c|c|}
\hline Place & State $^{a}$ & $\begin{array}{l}\text { Succession or dominant } \\
\text { plant }^{\mathrm{b}}\end{array}$ & $\begin{array}{c}\text { Reported soil } \\
\text { classification }\end{array}$ & Clay $(\%)$ & $\begin{array}{l}\text { Layer } \\
(\mathrm{cm})\end{array}$ & $\begin{array}{l}\text { Duration } \\
\quad(\mathrm{yr})\end{array}$ & $\begin{array}{c}\text { Rate } \\
\left(\mathrm{t} \mathrm{C} \text { ha }^{-1}\right)\end{array}$ & Source \\
\hline \multicolumn{9}{|c|}{ Cerrados region } \\
\hline \multirow[t]{2}{*}{ Planatina } & $\mathrm{DF}$ & $\mathrm{S} / \mathrm{W}$ & Oxisol & $40-50$ & $0-20$ & 15 & 0.5 & Corazza et al., 1999 \\
\hline & & & & & $0-40$ & 15 & 0.8 & \\
\hline Sinop & MT & $\begin{array}{l}\mathrm{R}-\mathrm{S} / \mathrm{So}-\mathrm{R} / \mathrm{So}-\mathrm{S} / \mathrm{M}- \\
\mathrm{S} / \mathrm{E}\end{array}$ & Oxisol & $50-65$ & $0-40$ & 5 & 1.7 & Perrin, 2003 \\
\hline Goiânia & GO & Rice/Soya & Oxisol & & $0-10$ & 5 & 0.7 & $\mathrm{Ud}$ \\
\hline Rio Verde & GO & $\begin{array}{l}\mathrm{M} \text { or } \mathrm{S} / \text { FallowS/M or So or } \\
\mathrm{Mi}\end{array}$ & Oxisol & $45-65$ & $0-20$ & 12 & 0.8 & Scopel et al., 2003 \\
\hline Not specified & $?$ & $\mathrm{M}$ or $\mathrm{S}$ & Oxisol & $>30$ & $0-40$ & 16 & 0.4 & Resck et al., 2000 \\
\hline \multicolumn{9}{|l|}{ South region } \\
\hline \multirow[t]{3}{*}{ Londrina } & PR & $\mathrm{W} / \mathrm{S}$ & Oxisol & & $0-10$ & 22 & 0.31 & $\begin{array}{l}\text { Machado \& Silva, } \\
2001\end{array}$ \\
\hline & & & & & $0-20$ & 22 & 0.25 & \\
\hline & & & & & $0-40$ & 22 & -0.17 & \\
\hline Londrina & PR & $\mathrm{S} / \mathrm{W}-\mathrm{S} / \mathrm{L}-\mathrm{M} / \mathrm{O}$ & Oxisol & & $0-20$ & 7 & $0.5-0.9$ & Zotarelli et al., 2003 \\
\hline \multirow[t]{2}{*}{ Londrina } & PR & $\begin{array}{l}\mathrm{S} / \mathrm{W} / \mathrm{S} \text { or } \mathrm{M} / \mathrm{W} / \mathrm{M} \text { or } \\
\mathrm{S} / \mathrm{W} / \mathrm{M}\end{array}$ & Typic Haplorthox & & $0-10$ & 14 & $0.4^{\mathrm{d}}$ & $\begin{array}{l}\text { Castro Filho et al., } \\
1998\end{array}$ \\
\hline & & & & & $0-20$ & & $0.2^{\mathrm{d}}$ & \\
\hline Londrina & PR & $\begin{array}{l}\mathrm{S} / \mathrm{W} / \mathrm{S} \text { or } \mathrm{M} / \mathrm{W} / \mathrm{M} \text { or } \\
\mathrm{S} / \mathrm{W} / \mathrm{M}\end{array}$ & Typic Haplorthox & & $0-40$ & 21 & $0^{\mathrm{c}}$ & $\begin{array}{l}\text { Castro Filho et al., } \\
2002\end{array}$ \\
\hline Ponta Grossa & PR & $(\mathrm{S}$ or $\mathrm{M}) /(\mathrm{O}$ or $\mathrm{W})$ & Typic Hapludox & $40-45$ & $0-40$ & 22 & 0.9 & Sá et al., 2001 \\
\hline Tibagi & PR & $(\mathrm{S}$ or $\mathrm{M}) /(\mathrm{O}$ or $\mathrm{W})$ & Typic Hapludox & $40-45$ & $0-40$ & 10 & -0.5 & Sá et al., 2001 \\
\hline Ponta Grossa & PR & S/T-S/A-M/T & Oxisol & $?$ & $0-20$ & 15 & 0.66 & Pavei, 2005 \\
\hline Tibagi & PR & $\mathrm{M} / \mathrm{W}-\mathrm{S} / \mathrm{O}-\mathrm{S} / \mathrm{O}$ & Oxisol & $40-45$ & $0-10$ & 22 & $1.0^{\mathrm{d}}$ & $\begin{array}{l}\text { Venzke Filho et al., } \\
2002\end{array}$ \\
\hline Tibagi & PR & $\mathrm{M} / \mathrm{W}-\mathrm{S} / \mathrm{O}-\mathrm{S} / \mathrm{O}$ & Oxisol & 42 & $0-20$ & 10 & 1.6 & Siqueira Neto, 2003 \\
\hline \multirow[t]{2}{*}{ Toledo } & PR & $\mathrm{S} / \mathrm{O}$ & Haplic Ferrasol & & $0-10$ & 3 & $-0.68^{d}$ & $\begin{array}{l}\text { Riezebos \& Loerts, } \\
1998\end{array}$ \\
\hline & & $\mathrm{S} / \mathrm{O}$ & Haplic Ferrasol & & $0-10$ & 10 & $0.37^{\mathrm{d}}$ & \\
\hline \multirow[t]{3}{*}{ Passo Fundo } & RS & $\mathrm{W} / \mathrm{S}$ & Oxisol & & $0-10$ & 11 & 0.59 & $\begin{array}{l}\text { Machado \& Silva, } \\
2001\end{array}$ \\
\hline & & & & & $0-20$ & 11 & -0.07 & \\
\hline & & & & & $0-40$ & 11 & 0.29 & \\
\hline \multirow[t]{3}{*}{ Passo Fundo } & RS & $\mathrm{W} / \mathrm{S}$ & Typic Hapludox & 63 & $0-30$ & 13 & $0^{\mathrm{c}}$ & Sisti et al., 2004 \\
\hline & & $\mathrm{W} / \mathrm{S}-\mathrm{V} / \mathrm{M}$ & & & $0-30$ & 13 & 0.4 & \\
\hline & & $\mathrm{W} / \mathrm{S}-\mathrm{O} / \mathrm{S}-\mathrm{V} / \mathrm{M}$ & & & $0-30$ & 13 & 0.7 & \\
\hline \multirow[t]{6}{*}{ Passo Fundo } & RS & $\mathrm{W} / \mathrm{S}$ & Typic Hapludox & 63 & $0-10$ & 11 & 0.3 & Freixo et al., 2002 \\
\hline & & & & & $0-20$ & 11 & $0^{c}$ & \\
\hline & & & & & $0-30$ & 11 & $0^{\mathrm{c}}$ & \\
\hline & & $\mathrm{W} / \mathrm{S}-\mathrm{W} / \mathrm{M}$ & Typic Hapludox & & $0-10$ & 11 & 0.4 & Freixo et al., 2002 \\
\hline & & & & & $0-20$ & 11 & 0.2 & \\
\hline & & & & & $0-30$ & 11 & $0^{c}$ & \\
\hline Santa Maria & RS & $\mathrm{M}$ and $\mathrm{Mu} / \mathrm{M}$ & Ultisol & 15 & $0-20$ & 4 & 1.3 & Amado et al., 2001 \\
\hline
\end{tabular}


Table 1 - Continuation.

\begin{tabular}{|c|c|c|c|c|c|c|c|c|}
\hline \multirow[t]{3}{*}{$\begin{array}{l}\text { Eldorado do } \\
\text { Sul }\end{array}$} & RS & $\mathrm{M} / \mathrm{G}$ & $\begin{array}{c}\text { Argissolo } \\
\text { vermelho escuro }\end{array}$ & & $0-17.5$ & 5 & $1.4^{\mathrm{d}}$ & Testa et al., 1992 \\
\hline & & $\mathrm{M} / \mathrm{La}$ & & & $0-17.5$ & 5 & $0.6^{\mathrm{d}}$ & \\
\hline & & $\mathrm{O} / \mathrm{M}$ & & & $0-17.5$ & 5 & $0.2^{\mathrm{d}}$ & \\
\hline $\begin{array}{l}\text { Eldorado do } \\
\text { Sul }\end{array}$ & $\mathrm{RS}$ & $\mathrm{O}+\mathrm{V} / \mathrm{M}+\mathrm{C}$ & Typic Paleudult & 22 & $0-17.5$ & 9 & 0.84 & Bayer et al., 2002 \\
\hline \multirow[t]{2}{*}{$\begin{array}{l}\text { Eldorado do } \\
\text { Sul }\end{array}$} & $\mathrm{RS}$ & $\mathrm{O} / \mathrm{M}$ & Typic Paleudult & 22 & $0-30$ & 9 & 0.51 & Bayer et al., 2000b \\
\hline & & $\mathrm{O}+\mathrm{V} / \mathrm{M}+\mathrm{C}$ & & & $0-30$ & 9 & 0.71 & \\
\hline $\begin{array}{l}\text { Eldorado do } \\
\text { Sul }\end{array}$ & $\mathrm{RS}$ & $\mathrm{O}+\mathrm{V} / \mathrm{M}+\mathrm{C}$ & TypicPaleudult & 22 & $0-17.5$ & 12 & 1.26 & Bayer et al., 2000a \\
\hline $\begin{array}{l}\text { Eldorado do } \\
\text { Sul }\end{array}$ & $\mathrm{RS}$ & $\mathrm{A} / \mathrm{M}$ & $\begin{array}{c}\text { Argissolo } \\
\text { Vermelho Escuro }\end{array}$ & & $0-17.5$ & 17 & 0.07 & Diekow et al., 2005 \\
\hline Lages & $\mathrm{SC}$ & $\mathrm{M}$ or $\mathrm{S} / \mathrm{W}$ or $\mathrm{O}$ & Cambissol & & $0-20$ & 8 & 1.0 & $\begin{array}{l}\text { Bayer \& Bertol, } \\
1999\end{array}$ \\
\hline \multicolumn{9}{|c|}{ Other regions } \\
\hline \multirow[t]{2}{*}{ Campinas } & SP & $\mathrm{S}$ or $\mathrm{C} / \mathrm{M}$ & Typic Haplorthox & 60 & $0-20$ & 3 & $0.8^{\mathrm{de}}$ & $\begin{array}{l}\text { De Maria et al., } \\
1999\end{array}$ \\
\hline & & & & & $0-20$ & 8 & $0.4^{\text {de }}$ & \\
\hline Coimbra & MG & $\mathrm{M} / \mathrm{P}$ or $\mathrm{S} / \mathrm{P}$ & Argissolo & 40 & $0-20$ & 15 & 0.49 & Leite et al., 2004 \\
\hline \multirow[t]{2}{*}{ Sete Lagoas } & MG & $\mathrm{M} / \mathrm{B}$ & Typic Haplustox & & $0-15$ & 10 & $0^{c}$ & $\begin{array}{l}\text { Roscoe \& Buurman, } \\
2003\end{array}$ \\
\hline & & & & & $0-45$ & & $0^{c}$ & \\
\hline
\end{tabular}

aPR =Parana, RS =Rio Grande do Sul, DF = Distrito Federal, $\mathrm{SC}=$ Santa Catarina, $\mathrm{SP}=$ São Paulo, MT = Mato Grosso, GO = Goiás, MG = Minas Gerais; ${ }^{b}$ Dominant succession: $\mathrm{W}=$ Wheat (triticum aestivum), $\mathrm{S}=$ Soybean $($ Glycine max), So $=$ Sorghum $($ Sorghum vulgaris), $\mathrm{R}=$ Rice (Oriza sativa), $\mathrm{E}=$ Eleusine coracana, $\mathrm{O}=$ Oat (Avena sativa), $\mathrm{V}=$ Vetch (Vicia sativa), $\mathrm{M}=\mathrm{Maize}($ Zea mays), $\mathrm{B}=$ Beans (Phaseolus vulgaris), $\mathrm{Mu}=$ Mucuna (Stizolobium cinereum), $\mathrm{C}=$ cowpea (Vigna unguiculata), $\mathrm{L}=\mathrm{Lupine}$ bean (Lupinus angustifollios), $\mathrm{La}=$ Lablabe (Dolicbos lablab), $\mathrm{G}=$ Guandu (Cajanus cajan); ${ }^{\mathrm{c}} 0$ means that the difference was not significant; ${ }^{\mathrm{d}}$ calculated using an arbitrary soil bulk density of $1.2 \mathrm{~g} \mathrm{~cm}^{-3}$; value reported for $\mathrm{OM}, \mathrm{C}=\mathrm{OM} / 1.724$, ud =unpublished data.

is a highly efficient converter of solar energy and, in fact, has the highest energy-to-volume ratio of all energy crops (Johnson, 2000). Sugar cane is a perennial crop that is harvested on an annual cycle. There may be up to six cycles before re-planting. There is generally only a short fallow between ploughing out the old cane and re-planting. On the majority of farms in Brazil sugar cane is grown as a monoculture (Macedo, 1997; Simões et al., 2005). It is a highly flexible resource, offering alternatives for production of food, feed, fibre and energy. Such flexibility is valuable in the developing world where fluctuations in commodity prices and weather conditions can cause severe economic hardships.

For biomass energy production, sugar cane is an excellent feedstock in terms of efficiency and flexibility, providing gaseous, liquid and solid fuels (Ripoli et al., 2000). It offers the potential for climate change mitigation through substitution of fossil fuels without the need for excessive subsidies or expensive infrastructure development (Oliveira et al., 2005).

The Brazilian ethanol programme remains the world's largest $\mathrm{CO}_{2}$ mitigation programme (Johnson, 2000; Oliveira et al., 2005). At present in Brazil, sugar cane is cultivated on about 5 million ha, with an aver- age annual production of approximately 300 million tonnes (FNP, 2006). In 1999/00 about 19 million tonnes of sugar and 12 million $\mathrm{m}^{3}$ of alcohol were produced (CENBIO, 2002).

There are two procedures adopted for sugar cane harvesting. Traditionally, sugar cane was burnt in the field a few days before harvesting in order to facilitate manual cutting by removing leaves and insects (Thorburn et al., 2001). However, since May 2000 this common practice has been progressively prohibited by law in some areas in Brazil. In addition to $\mathrm{CO}_{2}$ emission, other pollutant gases are emitted during the burning period causing respiratory problems and ash fall over urban areas (Andreae \& Merlet, 2001). Even though the law will not be fully implemented before 2030 , the adoption of mechanical harvesting has increased exponentially in Brazil during the last decade. In 1997 about $20 \%$ of the Brazilian sugar cane area was harvested by machines (Silva, 1997) and it is estimated that about $80 \%$ of the planted area in the most productive sugar cane region in Brazil will use mechanical harvesting in the next 20 years (CENBIO 2002).

The current mechanical approach is only adapted for slopes of less than $12 \%$ (Luca, 2002) and 
it seems likely that when the burning ban is fully implemented steeply sloping land will go out of sugar cane production unless new harvesting methods are developed (Simões et al., 2005). By the return of crop residues to the soil surface the mechanical approach has indirectly favoured soil organic matter accumulation (Thorburn et al., 2001; Luca, 2002) and gas emission reduction when compared to the burning system (Andreae \& Merlet, 2001).

The net contribution of the Brazilian sugar cane industry to the evolution of atmospheric $\mathrm{CO}_{2}$ is a combination of three activities, two industrial and one agricultural. The first activity is the substitution of gasoline as a fuel by alcohol. Since the early 1930's the Brazilian government has given incentives for alcohol production from sugar cane to be added to gasoline in the transportation sector (Sociedade Nacional de Agricultura, 2000). Due to the oil crises in 197374, Brazilian authorities created new incentives through the Brazilian alcohol program (Proalcool) to increase the production of alcohol to 10.7 billion litres per year (Coelho et al., 2000). During 1975 to 2000, 156 million $\mathrm{m}^{3}$ of hydrated alcohol and 71 million $\mathrm{m}^{3}$ of anhydrous alcohol were produced. Considering that $1 \mathrm{~m}^{3}$ of gasoline can be substituted by $1.04 \mathrm{~m}^{3}$ anhydrous alcohol and $0.8 \mathrm{~m}^{3}$ hydrated alcohol and that gasoline contains on average $86.5 \% \mathrm{C}$ (American Petroleum Institute, 1988) we calculate that during the 1975-2000 period, 172 Mt C were offset and consequently not emitted to the atmosphere, which gives an average annual offset of $6.8 \mathrm{Mt} \mathrm{C}$. However, the alcohol production and consumption are increasing every year in Brazil. If data just for the last 10 years were

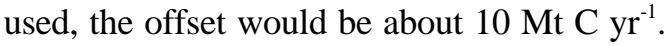

The second associated mitigation factor in the sugar cane system is related to the use of plant residues as a fuel. At the mill, the cane stalks are shredded and crushed to extract the cane juice while the fibrous outer residue, known as bagasse, is burnt to provide steam and electricity for the mill (Luca, 2002). For instance, in 1998 approximately 45 Mt dry matter of sugar cane residues were produced in Brazil (Brasil, 1999). Assuming that $2.35 \mathrm{t}$ of residues substitute for $1 \mathrm{t}$ of fossil fuel (Macedo, 1997) we estimate that 8 Mt C were offset in 1998 due to use of sugar cane residues at the mill instead of fuel. This renewable energy resource, found mainly in developing countries, has obvious appeal for international efforts to reduce carbon dioxide emissions. Moreover, the organic wastewater stream from alcohol production, known as vinasse, can be used as fertilizer or can be converted to methane gas through anaerobic digestion. The transportation fleets used in sugar factories and ethanol distilleries in Brazil have in some cases been powered by methane gas (Johnson, 2000). The production of alcohol has been viewed as a valuable means of saving foreign exchange in developing countries while at the same time providing local and global environmental benefits (Oliveira et al., 2005). In addition to climate mitigation and reduction of local pollutants, it can serve as an octane enhancer that might speed the phasing-out of leaded gasoline. The economic and environmental attractiveness of sugar cane as a renewable energy resource and the variety of options for increasing use of cane by-products and co-products could one day lead to sugar becoming the by-product rather than the main product.

Finally, the third activity associated with $\mathrm{CO}_{2}$ mitigation in the sugar cane system is the conversion harvesting without prior burning. At present there are 5 Mha of sugar cane grown in Brazil (FNP, 2006) of which approximately $20 \%$ (1.5 Mha) is harvested without burning (Silva, 1997; Oliveira et al., 2005). In the absence of burning, sugar cane residues are returned to the soil surface with litter and this factor is significant because it contrasts with the alternative system where cane is burnt before harvest removing dead and green leaves, so there is very little $\mathrm{C}$ returned to the soil from the above ground vegetation. For instance, Blair et al. (1998) found increases in the labile C fraction in green trash treatments as compared to the trash burnt treatments in the surface soils of two green trash management trials in Australia. In Southern Brazil, Feller (2001) reported that an average of $0.32 \mathrm{t} \mathrm{C} \mathrm{ha}^{-1}$ $\mathrm{yr}^{-1}$ was accumulated in 12 years in the first $20 \mathrm{~cm}$ depth of an Oxisol due to the elimination of burning. Other estimates exist, but for shorter periods of noburning. For instance, Luca (2002) reported increases ranging from 2 to 3.1 and 4.8 to $7.8 \mathrm{t} \mathrm{C} \mathrm{ha}^{-1}$ respectively for the top $5 \mathrm{~cm}$ and $40 \mathrm{~cm}$ depth during the first 4 years following no-burning. The corresponding annual increase ranges from 0.5 to $0.78 \mathrm{t} \mathrm{C} \mathrm{ha}^{-1} \mathrm{yr}^{-1}$ for the $0-5 \mathrm{~cm}$ layer and 1.2 to $1.9 \mathrm{t} \mathrm{C} \mathrm{ha}^{-1} \mathrm{yr}^{-1}$ for the 0 $40 \mathrm{~cm}$ layer. However, sugar cane is typically replanted each 6-7 years and tillage practices are then commonly used. This procedure would probably reduce the high rates presented by Luca (2002) if the study had been for a longer period. In our estimate of $\mathrm{C}$ sequestration we have used the value found by Feller (2001) because it represents the longest period of harvest without burning in Brazil and incorporates cane replanting. Thus, considering the area under this management system and the mean annual $\mathrm{C}$ accumulation rate, a total of

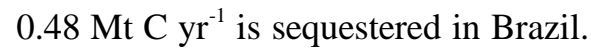

When sugar cane is burnt other greenhouse gases like $\mathrm{CH}_{4}$ and $\mathrm{N}_{2} \mathrm{O}$ are emitted to the atmosphere. Macedo (1998) shows that $6.5 \mathrm{~kg} \mathrm{CH}_{4} \mathrm{ha}^{-1}$ are released from the burning of sugar cane. Considering the total 
area with sugar cane under no burning harvesting system (1.5 Mha) and that the methane has the global warming potential of 21 , we have calculated that 0.2 $\mathrm{Mt} \mathrm{CO}_{2}$-equivalent $(0.05 \mathrm{Mt} \mathrm{C})$ that are not emitted annually to the atmosphere due to the adoption of no burning. The same calculation is required for $\mathrm{N}_{2} \mathrm{O}$ emission; however, currently there are no adequate measurements of this gas for sugar cane.

In summary, when sugar cane is harvested mechanically without burning in Brazil, 0.48 $\mathrm{Mt} \mathrm{C} \mathrm{yr}^{-1}$ is sequestered in soil and methane emission equivalent

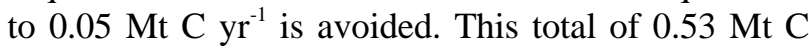
$\mathrm{yr}^{-1}$ is the contribution of the agricultural sector. Moreover, the industrial sector contributes not only the 10 Mt C $\mathrm{yr}^{-1}$ offset due to substitution of fossil fuel by alcohol for transportation but also the $8 \mathrm{Mt} \mathrm{C} \mathrm{yr}^{-1}$ by substituting fossil fuel for power generation at the mill. Combining the agricultural and the industrial sectors, sugar cane produced without burning gives a total of

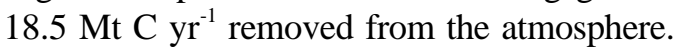

\section{Sequestration opportunities}

The cultivated area under no-tillage in Brazil is increasing rapidly at an average of 2.4 million ha per year over the last five years. Assuming the same growth pattern, projections show that in less than ten years the cultivated area under no-tillage will be doubled. Consequently, estimated values for soil $\mathrm{C}$ accumulation (10 $\mathrm{Mt} \mathrm{C} \mathrm{yr}^{-1}$ ) presented may be doubled in the next 10 years.

The no burning harvest system adopted on $20 \%$ of the crop in Brazil contributing through soil C sequestration and $\mathrm{C}$ offset at a rate of $18.5 \mathrm{Mt} \mathrm{C} \mathrm{yr}^{-1}$. This rate is going to increase substantially as the noburning system is expected to reach 50\% of the crop in the next decade (Macedo, 1998).

Estimated annual fluxes for Brazilian agriculture indicate a net emission of $46.4 \mathrm{Mt} \mathrm{CO}_{2}$ (or 12.65 Mt C) to the atmosphere for the period 1975-1995. However, the main changes in agricultural management discussed in this report contribute together to $\mathrm{CO}_{2}$

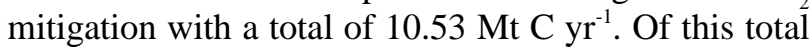
$10 \mathrm{Mt} \mathrm{C} \mathrm{yr}^{-1}$ relates to adoption of no-tillage and 0.53 $\mathrm{Mt} \mathrm{C} \mathrm{yr}^{-1}$ relates to introduction of sugar cane harvesting without burning. The implementation of these two practices is almost sufficient to compensate for the net soil emissions of $12.65 \mathrm{Mt} \mathrm{C} \mathrm{yr}^{-1}$.

Apparently, no-tillage is more effective in sequestering $\mathrm{C}$ than harvesting cane without burning. However, we should emphasize that the area under notillage is about 10 times greater than the area under sugar cane. The $\mathrm{C}$ sequestration rate per unit area under no-tillage is slightly more than the rate for no burning. If the $\mathrm{CO}_{2}$-equivalent of $\mathrm{N}_{2} \mathrm{O}$ emitted during burn- ing of sugar cane is subtracted, these rates would probably be similar. In addition to the $\mathrm{CO}_{2}$ mitigation benefit due to no-tillage sugar cane has extra benefits derived from the substitution of fossil fuel by alcohol and bagasse.

In addition to the $\mathrm{CO}_{2}$ mitigation related to the main management practices here discussed, the adoption of good management strategies has the potential to raise soil $\mathrm{C}$ levels and consequently improve soil structure. This results in increased infiltration, better soil water relations, reduced surface sealing and erosion which should lead to increased crop yields. The improvement and maintenance of soil $\mathrm{C}$ and soil structure is necessary for sustainable agricultural systems and conservation of the soil resource.

\section{Impact of climate change on soil organic matter sta- tus in cattle pasture in Western Brazilian Amazon}

Most studies concerning the impact of climate change on food security deal with grain production only. But beef production, with 175 million cattle in 2001, represents a large component of Brazilian agriculture. About $30 \%$ of the total is in the Amazon region where pastures are typically extensively managed and are on low fertility soils. The sustainability of these fragile ranching systems can be evaluated through the soil organic matter (SOM) status. A changing climate can induce losses of soil organic matter, upsetting the input-output nutrient balance and provoke losses in plant grass productivity, and subsequently sustainability of the overall system.

The main objective of this section was to estimate changes induced by potential climatic change on soil organic matter stocks in extensive pastures of the Brazilian Amazon region, using a modeling approach. In order to do so, we have applied the Century Ecosystem Model (Century 4.0) using Tyndall Center climatic predictions to simulate soil carbon stocks and fluxes in a chronosequence of forest to pasture located within the Nova Vida Ranch in the Rondônia State, in the western part of the Brazilian Amazon.

Nova Vida Ranch - It covers an area of 22,000 ha and is a mixture of native forest and well managed pastures of different ages. The climate of the region is humid tropical, with a dry season from May to September. Annual rainfall is $2200 \mathrm{~mm}$. Annual mean temperature is $25.6^{\circ} \mathrm{C}$. Mean temperature for the warmest and coolest months varies by less than $5^{\circ} \mathrm{C}$ and mean annual relative humidity is $89 \%$ (Bastos \& Diniz, 1982). Soils are classified as Argissolo Vermelho-Amarelo by the Brazilian classification scheme and as Ultisols (Kandiuldults) in the U.S. soil taxonomy (Moraes et al., 1995). 
The Century Ecosystem Model - Century is a model of soil organic matter and nutrient dynamics that emphasizes the decomposition of soil organic matter and the flux of $\mathrm{C}$ and $\mathrm{N}$ within and between different components (Parton et al., 1987). The grassland/crop and forest systems have different plant production submodels that are linked to a common soil organic matter and nutrient cycling submodel, which has been fully described before (Metherell et al., 1993; Paustian et al., 1997).

Climate Change Scenarios - For our soil C stock simulations, we modified the current climatic data (Table 2) measured at the study area, using Tyndall Center predictions (TYN CY 3.0 dataset for Brazil available at http://www.cru.uea.ac.uk/ timm/grid/ table.html). Details on the TYN SC 3.0 dataset are fully reported by Mitchell et al. (2004). Briefly The TYN CY 3.0 dataset comprises predicted climate, for the period 2001-2100. There are five climatic variables available: cloud cover, diurnal temperature range, precipitation, temperature, vapor pressure. There are 16 climate change scenarios making up all permutations of four GCM models (GCMM2, CSIRO mk 2, DOE PCM and HadCM3; these models are used by the IPCC, 2001) with four contrasting emission scenarios (A1F1, A2, B2, B1) used by IPCC SRES scenarios (IPCC, 2001). This study is based on results from HadCM3 model combined with A1F1 SRES scenario (HadCM3- A1F1), and DOE PCM model with B1 (DOE PCM - B1), covering the maximum range in temperature and precipitation changes applied to actual data registered for the Nova Vida region.
Data from the Tyndall Center predicted that scenario HadCM3-A1F1 would cause an increase of $6.7^{\circ} \mathrm{C}$ in the annual mean temperature and a decrease of $461 \mathrm{~mm}$ in the annual mean precipitation. Scenario DOE PCM-B1 indicated smaller variations in annual temperature and precipitation as compared to the former scenario, i.e, only $1.3^{\circ} \mathrm{C}$ in temperature increase and $50 \mathrm{~mm}$ increase in the annual mean precipitation (Mitchell et al., 2004). It is important to emphasize that modifications made on actual data (Table 2) were performed using specific simulated results of temperature and precipitation for each month of the year (i.e, we did not spread simulated climatic differences uniformly throughout the year). Preserving the monthly differences in temperature and precipitation is important in areas where there are marked differences between wet and dry seasons, which is the case for our study area.

Impact of climate change on soil organic matter The effects of the conversion of tropical forest to pasture on total soil C, using current weather data (Table 2), was analyzed in detail by Cerri et al. (2004), using the Century model and chronosequence data collected from the Nova Vida ranch, Western Brazilian Amazon. First, the model was applied to estimate equilibrium organic matter levels, plant productivity and residue carbon inputs under native forest conditions. Then Century was set to simulate the deforestation following slash and burn. Soil organic matter dynamics was simulated for pastures established in 1989, 1987, 1983, 1979, 1972, 1951 and 1911.

Using input data from the Nova Vida ranch, the Century model predicted that forest clearance and con-

Table 2 - Actual (measured at a local meteorological station) and predicted (according to Tyndall Center predictions) weather data for the Nova Vida Ranch. Adapted from Cerri et al. (2005).

\begin{tabular}{|c|c|c|c|c|c|c|c|c|c|}
\hline \multirow{2}{*}{ Month } & \multicolumn{3}{|c|}{ Actual data } & \multicolumn{3}{|c|}{ HadCM3 - A1F1 } & \multicolumn{3}{|c|}{ DOE PCM - B1 } \\
\hline & Prec & $\mathrm{T} \max$ & $\mathrm{T} \min$ & Prec & $\mathrm{T} \max$ & $\mathrm{T} \min$ & Prec & $\mathrm{T} \max$ & $\mathrm{T} \min$ \\
\hline & $\mathrm{cm}$ & \multicolumn{2}{|c|}{-.....- ${ }^{\circ} \mathrm{C}-\ldots$} & $\mathrm{cm}$ & \multicolumn{2}{|c|}{-...-. ${ }^{\circ} \mathrm{C}-\ldots$} & $\mathrm{cm}$ & \multicolumn{2}{|c|}{-.....- ${ }^{\circ} \mathrm{C}-\ldots$} \\
\hline Jan & 38.5 & 34.0 & 18.7 & 33.0 & 40.1 & 12.6 & 38.4 & 35.1 & 17.6 \\
\hline Feb & 39.2 & 27.6 & 15.3 & 35.5 & 33.2 & 9.7 & 39.1 & 28.6 & 14.3 \\
\hline Mar & 33.3 & 27.0 & 15.4 & 28.3 & 33.0 & 9.4 & 33.2 & 28.1 & 14.3 \\
\hline Apr & 17.4 & 31.4 & 23.6 & 14.5 & 38.0 & 17.0 & 17.3 & 32.7 & 22.3 \\
\hline May & 17.7 & 32.4 & 19.6 & 14.9 & 39.6 & 12.4 & 17.7 & 33.7 & 18.3 \\
\hline Jun & 5.8 & 32.9 & 18.9 & 3.2 & 40.2 & 11.6 & 5.8 & 34.3 & 17.5 \\
\hline Jul & 3.4 & 33.9 & 25.3 & 1.8 & 41.3 & 17.9 & 3.3 & 35.2 & 24.0 \\
\hline Aug & 3.1 & 32.9 & 24.1 & 1.5 & 39.9 & 17.1 & 3.1 & 34.4 & 22.6 \\
\hline Sep & 11.1 & 32.2 & 23.5 & 8.3 & 39.0 & 16.7 & 11.0 & 33.5 & 22.2 \\
\hline Oct & 16.2 & 28.0 & 18.3 & 11.3 & 35.0 & 11.3 & 16.1 & 29.5 & 16.8 \\
\hline Nov & 29.7 & 31.9 & 20.7 & 23.3 & 38.8 & 13.8 & 29.6 & 33.2 & 19.4 \\
\hline Dec & 33.0 & 34.3 & 24.3 & 26.8 & 40.9 & 17.7 & 32.9 & 35.5 & 23.1 \\
\hline
\end{tabular}

Prec: montly mean precipitation; T max: montly mean maximum air temperature; $\mathrm{T}$ min: montly mean minimum air temperature. 
version to pasture would cause an initial fall in the soil C stocks, followed by a slow rise to levels exceeding those under native forest (Figure 3). The model predicted the longer-term changes in soil $\mathrm{C}$ under pasture close to those inferred from the pasture chronosequence. Mean differences between simulated and observed values were about $9.32 \mathrm{~g} \mathrm{~m}^{-2}$ for total soil C (data not shown). After approximately 80 years under pasture cultivation, simulated results showed that soils of the Nova Vida Ranch chronosequence sequestered about $1.7 \mathrm{~kg} \mathrm{C} \mathrm{m}^{-2}$ in comparison to the levels presented by the soil under native forest (Figure 3). Bearing in mind that this figure is model-derived, it is interesting to observe that soil $\mathrm{C}$ stocks increase even for a period longer than 100 years. On the other hand, many studies related to soil $\mathrm{C}$ sequestration suggest that there is probably a limit for nutrient storage in a determined soil type under specific climatic and management conditions (Lal, 2006).

Simulated effects of climate change scenarios suggested by the Tyndall Center (Mitchell et al., 2004) on soil C stock dynamics at the Nova Vida Ranch forest to pasture chronosequence are shown on Figure 4. Notice that the same parameterization procedures were adopted in the three simulated conditions (current climate, HadCM3-A1F1 and DOE PCM-B1), except for the climatic variables temperature and precipitation, which were modified (Table 2) according to the criteria discussed before.

Simulated results gave similar curve shapes for all the three modeled situations, i.e., an initial decline in soil $\mathrm{C}$ stock in the first two-three years, following conversion from forest to pasture, and then a steady increase during pasture establishment. Small differences of simulated soil $\mathrm{C}$ dynamics between DOE PCM-B1 and HadCM3-A1F1 scenarios can be observed. For instance, in the first 16-17 years after de-

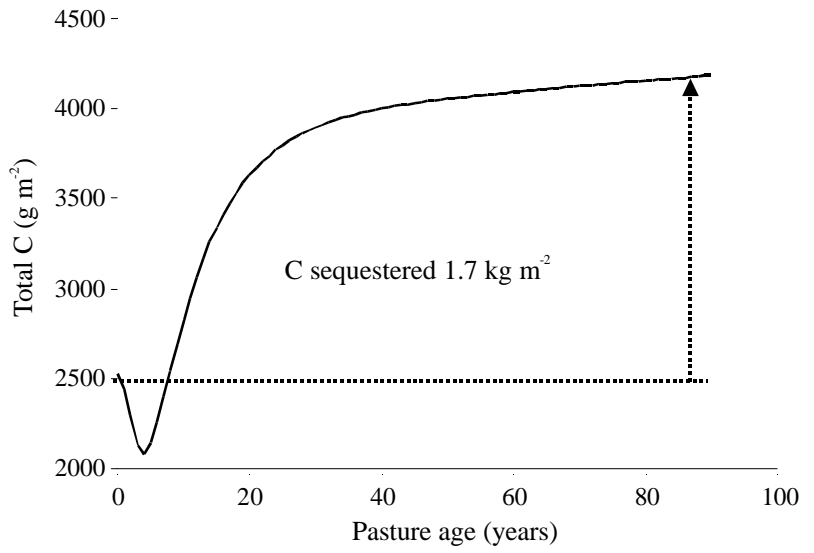

Figure 3 - Simulated result of soil $\mathrm{C}$ content in the 0 to $20 \mathrm{~cm}$ layer at the forest to pasture chronosequence located at Nova Vida Ranch, Rondônia State, Amazon. Adapted from Cerri et al. (2005). forestation, scenario DOE PCM-B1 presented slightly higher soil $\mathrm{C}$ stock results as compared to the HadCM3-A1F1 scenario. Around year 20, the difference between those two-modeled conditions disappeared. Moreover, after about 80 years of pasture cultivation, simulated results showed an inversion of the pattern presented in the early period, i.e, soil $\mathrm{C}$ stock results were approximately $2 \%$ higher for the HadCM3-A1F1 scenario as compared to DOE PCMB1 (Figure 4).

According to Century model predictions, Nova Vida chronosequence soils under current climate conditions would store much more $\mathrm{C}$ in the $0-20 \mathrm{~cm}$ layer than the other two considered scenarios. Actually, simulated results applying weather data measured at the study area indicated that soil would sequester about $4160 \mathrm{~g}$ $\mathrm{C} \mathrm{m}^{-2}$ after 80 years of continuous well managed pasture cultivation, which is approximately $400 \mathrm{~g} \mathrm{C} \mathrm{m}^{-2}$ and $465 \mathrm{~g} \mathrm{C} \mathrm{m}^{-2}$ more than the scenarios HadCM3-A1F1 and DOE PCM-B1, respectively (Figure 4).

Despite the enhancement in annual mean temperature of $1.3^{\circ} \mathrm{C}$ or $6.7^{\circ} \mathrm{C}$ (scenarios DOE PCM-B1 and HadCM3-A1F1, respectively), simulated results for those scenarios did not reflect in an increase of soil C stocks compared to the levels accomplished by actual weather data scenario. A plausible reason for this condition may be directly related to the Century model decomposition structure and concept. In the Century model, average monthly soil temperature near to the soil surface is calculated using equations developed by Parton et al. (1987). These equations calculate maximum soil temperature as a function of the maximum air temperature and the canopy biomass (lower for high biomass) while minimum soil temperature is a function of the minimum air temperature and canopy biomass (higher for high biomass). The actual soil temperature used for decomposition and plant growth rate

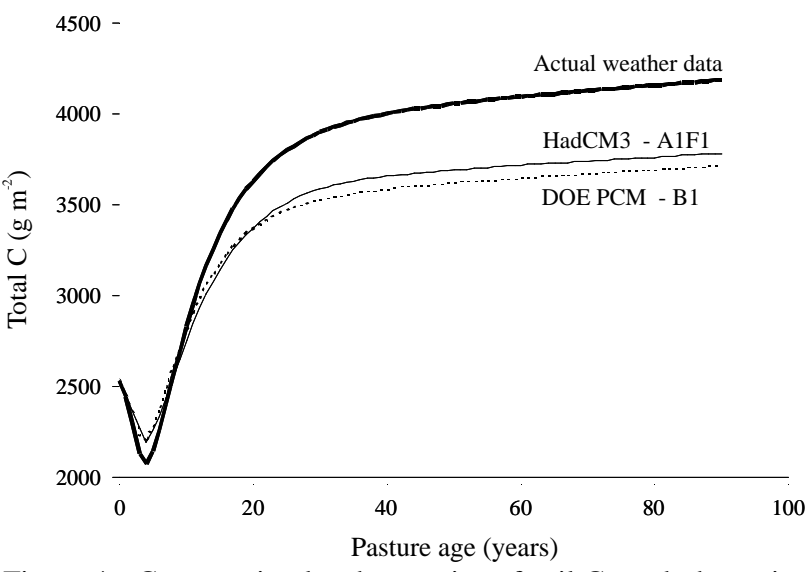

Figure 4 - Century simulated scenarios of soil C stock dynamics at the Nova Vida Ranch forest to pasture chronosequence, applying Tyndall Center predictions. Adapted from Cerri et al. (2005). 
functions is the average of the minimum and maximum soil temperature (Metherell et al., 1993). Therefore, increasing temperature by $1.3^{\circ} \mathrm{C}$ or $6.7^{\circ} \mathrm{C}$ increases simulated decomposition rates, reducing the storage rates of $C$ into the surface soil layer (Figure 4).

Moreover, the former inference of decomposition levels would probably occur more intensively in the slow $\mathrm{C}$ pool, which is responsible for about $68 \%$ of the total $\mathrm{C}$ in the first $20 \mathrm{~cm}$ soil depth (Figure 5). As expected, independent of the soil $\mathrm{C}$ pool (active, slow, or passive), simulated results followed the same pattern presented in Figure 4, i.e, the highest soil C content corresponds to simulations applying actual weather data and the lowest to simulations using climatic predictions from DOE PCM-B1 scenario.

The decomposition of soil organic matter in the Century model is assumed to be microbially mediated with an associated loss of $\mathrm{CO}_{2}$ as a result of microbial respiration. The potential decomposition rate is reduced by multiplicative functions of soil moisture and soil temperature. Decomposition products flow into one of the three soil organic matter pools, each characterized by different maximum decomposition rates (Metherell et al., 1993). The active pool (Figure 5) represents soil microbes and microbial products and has a turnover time of months to a few years depending on the environment. Soil texture influences the turnover rate of the active soil organic matter (higher rates for sandy soils) and the efficiency of stabilizing active into slow soil organic matter. The slow pool in Figure 5 includes resistant plant material derived from the structural pool and soil-stabilized microbial products derived from the active and surface microbe pools. It has a turnover time of 20 to 50 years. Finally, the passive pool is very resistant to decomposition and includes physically and chemically stabilized soil organic matter, has a turnover time of 400 to 2000 years.

From the standpoint of soil $\mathrm{C}$ sequestration, the ideal situation is to store $\mathrm{C}$ in the passive pool, due to

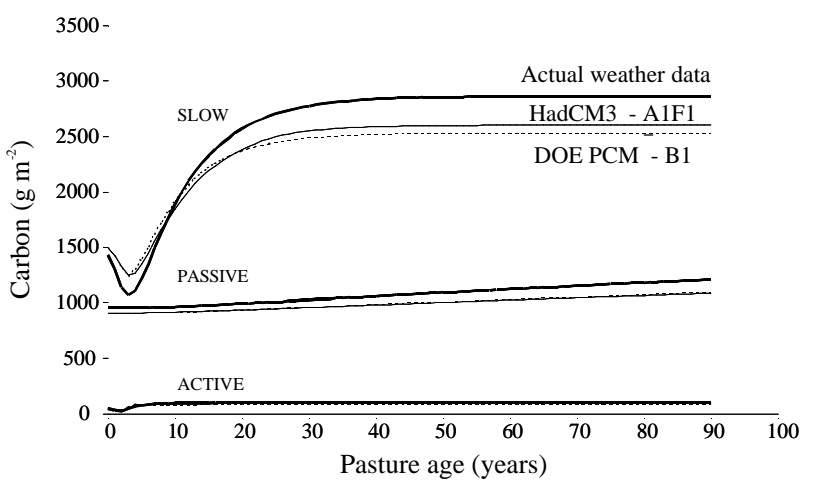

Figure 5 - Simulated soil $\mathrm{C}$ pools in the $0-20 \mathrm{~cm}$ layer, using actual weather data, HadCM3 - A1F1 and DOE PCM - B1 scenarios for the conditions of forest-to-pasture chronosequence. its stabilized state and long turnover time. Analyzing the simulated result presented in Figure 5 it is possible to verify that about $29 \%$ of the total C content is in the passive pool. Moreover, simulated values are increasing steadily throughout the simulation period and not maintaining a constant level as in the active pool.

The climate change scenarios impact other soil chemical, physical, and biological properties that we could not directly validate with measured data from the Nova Vida Ranch chronosequence. Another important aspect related to soil $\mathrm{C}$ dynamics in the Amazon region which we have not dealt with here is related to pasture management. Fearnside \& Barbosa (1998) showed that trends in soil carbon were strongly influenced by pasture management. Sites that were judged to have been under bad management generally lost soil $\mathrm{C}$, whereas sites under improved management had gained carbon. Trumbore et al. (1995) reported soil C losses in overgrazed pasture but soil $\mathrm{C}$ gains from fertilized pasture in the Amazon region. Neill et al. (1997) discussed that degraded pastures with little grass cover probably will be less likely to accumulate soil $\mathrm{C}$ because inputs to soil organic $\mathrm{C}$ from pasture roots will be diminished, but that might not be true in more vigorous regrowing secondary forest. Greater grazing intensity and soil damage from poor management would in all likelihood cause soil C and N losses. Similar processes that influence magnitude of annual soil organic matter inputs also regulate the accumulation of soil $\mathrm{C}$ in soils of North American grasslands (Conant et al., 2001).

We have also simulated changes in above and belowground plant productivity for pastures at the Nova Vida ranch, using weather data from current (actual data), HadCM3 - A1F1 and DOE PCM - B1 scenarios (Table 3). Modeled results showed a decrease in above and belowground productivity of $4 \%$ using DOE PCM - B1 data and about $20 \%$ reduction using data from HadCM3 - A1F1 compared to the plant productivity simulated for the current scenario (Table 3). Those simulated results suggest that climate change would cause a reduction in cattle stock rate (animals per ha) for pastures within the Nova Vida Ranch.

Table 3 - Simulated changes in plant productivity of pastures at Nova Vida Ranch, using current (actual data), HadCM3 - A1F1 and DOE PCM - B1 scenarios.

\begin{tabular}{|c|c|c|}
\hline \multirow{2}{*}{ Scenario } & \multicolumn{2}{|c|}{ Simulated plant productivity } \\
\hline & Aboveground & Belowground \\
\hline & \multicolumn{2}{|c|}{ - $\mathrm{g} \mathrm{m}^{2} \ldots$} \\
\hline Current (actual data) & 520 & 411 \\
\hline DOE PCM - B1 & 500 & 392 \\
\hline HadCM3 - A1F1 & 416 & 333 \\
\hline
\end{tabular}


Modeling provides a flexible and powerful way to assess how different scenarios of climate and land use changes can affect soil $\mathrm{C}$ dynamics. Literature information emphasizes that the conversion of forest to pasture is an important source of greenhouse gas emission, notably $\mathrm{CO}_{2}$ to the atmosphere. Globally, land use changes are responsible for about $14 \%$ of the total emissions. Research on soil organic matter dynamics under well-managed pastures has shown that soil organic carbon stocks progressively increase with time of pasture cultivation. This means that if considered in isolation, soils under well-managed pastures can be considered as a $\mathrm{CO}_{2}$ sink. However, when the whole system is evaluated, including the slash and burn process, it acts as a source of $\mathrm{CO}_{2}$ to the atmosphere. The disequilibrium between inputs and outputs of carbon can be aggravated if we consider the simulations performed in the present study. The scenarios used here indicated that there is a negative feedback in the soil carbon stocks due to increased temperature caused by climate change. Under this new climatic condition, the soil carbon accumulation rate under Amazonian pasture tends to decrease, reducing therefore, its atmospheric $\mathrm{CO}_{2}$ mitigation effect.

\section{CONCLUDING REMARKS}

Climate change and variability, drought and other climate-related extremes have a direct influence on the quantity and quality of agricultural production and in many cases, adversely affect it. Therefore, better agrometeorological adaptation strategies to increasing climate variability and climate change, especially in vulnerable regions where agriculture production is most sensitive to climatic fluctuations, are essential to avoid negative impacts on social and economic development.

\section{ACKNOWLEDGEMENTS}

To FAPESP (05/60255-6), CAPES, CNPq and NASA (05-LBA/05-18) for financial support and scholarship.

\section{REFERENCES}

AMADO, T.J.; FERNANDEZ, S.B.; MIELNICZUK, J. Nitrogen availability as affected by ten years $f$ cover crop and tillage systems in southern Brazil. Journal of Soil \& Water Conservation, v.53, p.268-271, 1998.

AMADO, T.J.; PONTELLI, C.B.; JÚNIOR, G.G.; BRUM, A.C.R.; ELTZ, F.L.F.; PEDRUZZI, C. Seqüestro de carbono em sistemas conservacionistas na Depressão Central do Rio Grande do Sul. In: REUNIÓN BIENAL DE LA RED LATINO AMERICANA DE AGRICULTURA CONSERVACIONISTA, 5 ., Florianópolis, 1999. Proceedings. Florianópolis: UFSC, 1999. p.42-43.
AMADO, T.J.; BAYER, C.; ELTZ, F.L.F.; BRUM, A.C.R. Potencial de culturas de cobertura em acumular carbono e nitrogênio no solo no plantio direto e a melhoria da qualidade ambiental. Revista Brasileira de Ciência do Solo, v.25, p.189-197, 2001.

AMERICAN PETROLEUM INSTITUTE. Alcohols and ethers. Washington, 1988. 34p. (Publication, 4261).

ANDREAE, M.O.; MERLET, P. Emission of trace gases and aerosols from biomass burning. Global Biogeochemical Cycles, v.15, p.955966, 2001

ASSAD, E.D.; PINTO, H.S.; ZULLO JR., J.; ÁVILA, A.H. Impacto das mudanças climáticas no zoneamento agroclimático do café no Brasil . Pesquisa Agropecuaria Brasileira, v.39, p.1057-1064, 2004.

BASTOS, T.X.; DINIZ, A.S. Avaliação do clima do Estado de Rondônia para desenvolvimento agrícola. Belém: EMBRAPA, CPATU, 1982. 28p. (Boletim de Pesquisa, 44).

BAYER, C.; BERTOL, I. Caracteristicas quimicas de um cambissolo humico afetadas por sistemas de preparo, com ênfase a matéria orgânica, Revista Brasileira de Ciência do Solo, v.23, p.687-694, 1999.

BAYER, C.; MARTIN-NETO, L.; MIELNICZUK, J.; CERETTA, C.A. Effect of no-till cropping systems on soil organic matter in a sandy clay loam Acrisol from southern Brazil monitored by electron spin resonance and nuclear magnetic resonance. Soil \& Tillage Research, v.53, p.95-104, 2000a.

BAYER, C.; MIELNICZUK, J.; AMADO, T.J.C.; MARTIN-NETO, L.; FERNANDES, S.V. Organic matter storage in a sandy clay loam Acrisol affected by tillage and cropping systems in southern Brazil. Soil \& Tillage Research, v.54, p.101-109, 2000b.

BAYER, C.; MIELNICZUK, J.; MARTIN-NETO, L.; ERNANI, P.R. Stocks and humification degree of organic matter fractions as affected by no-tillage on a subtropical soil. Plant and Soil, v.238, p.133140,2002

BERNOUX, M.; CARVALHO, M.C.S.; VOLKOFF, B.; CERRI, C.C. $\mathrm{CO}_{2}$ emission from mineral soils following land-cover change in Brazil. Global Change Biology, v.7, p.779-787, 2001.

BERNOUX, M.; CARVALHO, M.C.S.; VOLKOFF, B.; CERRI, C.C. Brazil's soil carbon stocks. Soil Science Society of America Journal, v.66, p.888-896, 2002.

BERNOUX, M.; CERRI, C.C.; CERRI, C.E.P.; SIQUEIRA NETO, M.; METAY. A.; PERRIN, A.S.; SCOPEL, E.; BLAVET, D.; PICCOLO, M.C.; PAVEI, M.; MILNE, E. Cropping systems, carbon sequestration and erosion in Brazil, a review. Agronomy for Sustainable Development, v.26, p.1-8, 2006.

BERTOL, I.; GUADAGNIN, J.C.; GONZALEZ, A.P.; AMARAL, A.J.; BRIGNONI, L.F. Soil tillage, water erosion, and calcium, magnesium and organic carbon losses. Scientia Agricola, v.62, p.578-584, 2005.

BLAIR, G.J.; CHAPMAN, L.; WHITBREAD, A.M.; BALL-COELHO, B.; LARSEN, P.; TIESSEN, H. Soil carbon changes resulting from trash management at two locations in Queensland, Australia and in North-east Brazil. Australian Journal of Soil Research, v.36, p.873882,1998

BRASIL. Ministério da Ciência e Tecnologia. Comunicação Nacional Inicial do Brasil à Convenção-Quadro das Nações Unidas sobre Mudança do Clima. Coordenação-Geral de Mudanças Globais de Clima. Brasília, 2004. 74p. (Comunicação Nacional).

BRASIL. Ministério das Minas e Energia. Balanço Energético Brasileiro. Brasília, 1999. Available in: <http://www.brasilrounds.gov.br/infogeral/balanco.htm>. Accessed in: 10 feb. 2002.

BURDON, J.J.; THRALL, P.H.; ERICSSON, L. The current and future dynamics of disease in plant communities. Annual Review of Phytopathology, v.44, p.19-39, 2006.

CAMBARDELLA, C.A.; ELLIOTT, E.T. Particulate soil organic matter changes across a grassland cultivation sequence. Soil Science Society of America Journal, v.56, p.777-783, 1992.

CASTRO FILHO, C.; MUZILLI, O.; PODANOSCHI, A.L. Estabilidade dos agregados e sua relação com o teor e carbono orgânico num latossolo distrófico, em função de sistemas de plantio, rotações de culturas e métodos de preparo das amostras. Revista Brasileira de Ciencia do Solo, v.22, p.527-538, 1998. 
CASTRO FILHO, C.; LOURENÇÃO, A.; GUIMARÃES, M. de F.; FONSECA, I.C.B. Aggregate stability under different soil management systems in a Red Latosol in State of Parana, Brazil. Soil Tillage Research, v.65, p.45-51, 2002.

CENBIO. Banco de dados de biomassa no Brasil. 2002. Available in: $\langle$ http://infoener.iee.usp.br/cenbio〉. Accessed in: 10 dec. 2002.

CERRI, C.C.; BERNOUX, M.; CERRI, C.E.P.; PAUSTIAN, K. Impact of climate change on SOM status in cattle pasture in western Brazilian Amazon. In: LAL, R.; UPHOFF, N.; STEWART, B.A.; HANSEN, D.O. (Ed.). Climate change and global food security. Boca Raton: CRC Press, 2005. chap.9, p.223-240.

CERRI, C.E.P.; PAUSTIAN, K.; BERNOUX, M.; VICTORIA, R.L.; MELLILO, J.M.; CERRI, C.C. Modeling changes in soil organic matter in Amazon forest to pasture conversion, using the Century model. Global Change Biology, v.10, p.815-832, 2004.

COELHO, S.T.; BOLOGNINI, M.F.; PALETTA, C.E.M. Proalcool: the Brazilian alcohol program. GreenTimes, v.7, p.1-2, 2000.

CONANT, R.T.; PAUSTIAN, K.; ELLIOTT, E.T. Grassland management and conversion into grassland: effects on soil carbon. Ecological Applications, v.11, p.343-355, 2001.

CORAZZA, E.J.; SILVA, J.E.; RESCK, D.V.S.; GOMES, A.C. Comportamento de diferentes sistemas de manejo como fonte ou depósito de carbono em relação a vegetação de Cerrado. Revista Brasileira de Ciência do Solo, v.23, p.425-432, 1999.

DE MARIA, I.C.; NNABUDE, P.C.; CASTRO, O.M. Long-term tillage and crop rotation effects on soil chemical properties of a Rhodic Ferralsol in southern Brazil, Soil \& Tillage Research, v.51, p.7179, 1999.

DENARDIN, J.E.; KOCHHANN, R.A. Requisitos para a implementação e a manutenção do plantio direto. In: EMBRAPA-CNPT-, FUNDACEP-FETRIGO, Fundação ABC. Plantio direto no Brasil. Passo Fundo: Editora Aldeia Norte, 1993. cap.2, p. 19-27.

DICK, W.A.; DURKALSKI, J.T. No-tillage production agriculture and carbon sequestration in a Typic Fragiudalf soil of Northeastern Ohio. In: LAL, R.; KIMBLE, J.; FOLLETT, R.F.; STEWART, B.A. (Ed.). Management of carbon sequestration in soil. Boca Raton: CRC Press, 1997. p.59-71.

DIEKOW, J.; MIELNICZUK, J.; KNICKER, H.; BAYER, C.; DICK, D.P.; KÖGEL-KNABNER, I. Soil C and N stocks affected by cropping systems and nitrogen fertilization in a southern Brazil Acrisol managed under no-tillage for 17 years. Soil \& Tillage Research, v.81, p.87-95, 2005.

EASTERLING, W.E.; APPS, M. Assessing the Consequences of Climate Change for Food and Forest Resources: A View from the IPCC, Climatic Change, v.70, p.165-189, 2005.

EMPRESA BRASILEIRA DE PESQUISA AGROPECUÁRIA. Serviço Nacional de Levantamento e Conservação de Solos. Mapa de solos do Brasil. Rio de Janeiro: EMBRAPA, CNPS, 1981. Escala $1: 5,000,000$

EPSTEIN, P.R.; MILLS, E. Climate change futures: Health, ecological and economic dimensions. Boston: The Center for Health and the Global Environment, Harvard Medical School, 2005. Available in: <http://www.climatechangefutures.org >. Accessed in: 02 nov. 2005.

FAO. SPECIAL EVENT ON IMPACT OF CLIMATE CHANGE, PESTS AND DISEASES ON FOOD SECURITY AND POVERTY REDUCTION. 31st Session of the Committee on World Food Security. Rome, 2005.

FEARNSIDE, P.M. Tropical deforestation and global warming. Science, v.312, p.1137-1137, 2006.

FEARNSIDE, P.M.; BARBOSA, R.I. Soil carbon changes from conversion of forest to pasture in Brazilian Amazon. Forest Ecology and Management, v.108, p.147 166, 1998.

FEDERAÇÃO BRASILEIRA DE PLANTIO DIRETO NA PLALHA FEBRAPDP. Curitiba, 2006. Available in: <http:// www.febrapdp.org.br>. Accessed in: Oct $1^{\text {st }}, 2006$.

FELLER, C. Efeitos da colheita sem queima da cana-de-açúcar sobre a dinâmica do carbono e propriedades do solo. Piracicaba, 2001. 150p. (Final Report Fapesp Contract 98/12648-3).

FNP. Consultoria e Comercio. Agrianual 2006. Available in: <http:// www.fnp.com.br>. Accessed in: 14 jun. 2006.
FOLEY, J.A.; DEFRIES, R.; ASNER, G.P.; BARFORD, C.; BONAN, G.; CARPENTER, S.R.; CHAPIN, F.S.; COE, M.T.; DAILY, G.; GIBBS, H.K.; HELKOWSKI, J.H.; HOLLOWAY, T.; HOWARD, E.A.; KUCHARIK, C.J.; MONFREDA, C.; PATZ, J.A.; PRENTICE, I.C.; RAMANKUTTY, N.; SNYDER, P.K. Global consequences of land use. Science, v.309, p.570-574, 2005.

FREIXO, A.A.; MACHADO, P.L.O.A.; DOS SANDOS, H.P.; SILVA, C.A.; FADIGAS, F.S. Soil organic carbon and fractions of a Rhodic Ferralsol under the influence of tillage and crop rotation systems in southern Brazil, Soil \& Tillage Research, v.64, p.221230, 2002.

FUNDAÇÃO INSTITUTO BRASILEIRO DE GEOGRAFIA E ESTATÍSTICA - IBGE. Mapa de vegetação do Brasil. . Rio de Janeiro, 1988. Escala 1:5,000,000.

GARRETT, K.A.; DENDY, S.P.; FRANK, E.E.; ROUSE, M.N.; TRAVERS, S.E. Climate change effects on plant disease: Genomes to ecosystems. Annual Review of Phytopathology, v.44, p.489-509, 2006.

GHINI, R. Mudanças climáticas globais e doenças de plantas. Jaguariúna: Embrapa Meio Ambiente, 2005. 104p.

GHINI, R.; MORANDI, M.A.B. Biotic and abiotic factors associated with soil suppressiveness to Rhzictonia solani. Scientia Agricola, v.63, p.153-160, 2006.

GREGORY, P.J.; INGRAM, J.S.I.; BRKLACICH, M. Climate change and food security. Philosophical Transactions of the Royal Society. Biological Sciences, v.360, p.2139-2148, 2005.

HANSEN, J.; SATO, M.; NAZARENKO, L.; RUEDY, R.; LACIS, A.; KOCH, D.; TEGEN, I.; HALL, T.; SHINDELL, D.; STONE, P.; NOVAKOV, T.; THOMASON, L.; WANG, R.; WANG, Y.; JACOB, D.; HOLLANDSWORTH-FRITH, S.; BISHOP, L.; LOGAN, J.; THOMPSON, A.; STOLARSKI, R.; LEAN, J.; WILLSON, R.; LEVITUS, S.; ANTONOV, J.; RAYNER, N.; PARKER, D.; CHRISTY, J. Climate forcings in Goddard Institute for Space Studies SI2000 simulations. Journal of Geophysical Research, v.107, p.4347-4384, 2002.

HANSEN, J.; NAZARENKO, L.; RUEDY, R.; SATO, M.; WILLIS, J.; DEL GENIO, A.; KOCH, D.; LACIS, A.; LO, K.; MENON, S.; NOVAKOV, T.; PERLWITZ, J.; RUSSELL, J.; SCHMIDT, G.A.; TAUSNEV, N. Earth's energy imbalance: Confirmation and implications. Science, v.308, p.1431-1435, 2005.

HOUGHTON, R.A. Why are estimates of the terrestrial carbon balance so different? Global Change Biology, v.9, p.500-509, 2003.

INSTITUTO NACIONAL DE PESQUISAS ESPACIAIS - INPE. Amazônia: desflorestamento 2004-2005. São José dos Campos, 2006. Available in: 〈http://www.obt.inpe.br/prodes/>. Accessed in: 07 dec 2006.

INTERNATIONAL INSTITUTE FOR APPLIED SYSTEMS ANALYSIS - IIASA.. Global agro-ecological assessment for agriculture in the $21^{\text {st }}$ century. Vienna: IIASA, 2001. 33p.

INTERGOVERNMENTAL PANEL ON CLIMATE CHANGE - IPCC. Climate Change 2001: Impacts, adaptation \& vulnerability. Contribution of Working Group II to the Third Assessment Report of the Intergovernmental Panel on Climate Change. Cambridge: University Press, 2001. 1000p.

INTERGOVERNMENTAL PANEL ON CLIMATE CHANGE - IPCC. Good practice guidance for land use, land-use change and forestry. IPCC National Greenhouse Gas Inventories Programme. Kanagawa, 2003. 675p.

INTERGOVERNMENTAL PANEL ON CLIMATE CHANGE - IPCC. IPCC Guidelines for National Greenhouse Gas Inventories. Revised 1996 Bracknell, UK, 1997. 457p.

JOHNSON, F. Sugarcane resources in southern Africa. Tiempo: Global Warming and The Third World, v.35, p.1-4, 2000.

KARLEN, D.L.; CAMBARDELLA, C.A. Conservation strategies for improving soil quality and organic matter storage. In: CARTER, M.R.; STEWART, B.A., (Ed.). Structure and organic matter storage in agricultural soils. Boca Raton: CRC Press, 1996. p. 395420.

KERR, R.A. How hot will the greenhouse world be? Science, v.309, p.100, 2005 . 
KLADIVKO, E. Tillage systems and soil ecology. Soil and Tillage Research, v.61, p.61-76, 2001.

KNORR, W.; PRENTICE, I.C.; HOUSE, J.I.; HOLLAND, E.A. Longterm sensitivity of soil carbon turnover to warming. Nature, v.433, p.298-301, 2005.

LAL, R. Long-term tillage and maize monoculture effects on a tropical Alfisol in Western Nigeria. II. Soil chemical properties. Soil Tillage Research, v.42, p.161-174, 1997.

LAL, R. Soil processes and the greenhouse effect. In: LAL, R.; BLUM, W.H.; VALENTINE, C.; STEWART, B.A. (Ed.). Methods for assessment of soil degradation. Boca Raton: CRC Press, 1998. p.199-212.

LAL, R. Soil carbon dynamic in cropland and rangeland. Environmental Pollution, v.116, p.353-362, 2002.

LAL, R. Enhancing crop yields in the developing countries through restoration of the soil organic carbon pool in agricultural lands. Land Degradation and Development, v.17, p.197-209, 2006.

LAL, R.; KIMBLE, J.; FOLLETT, R.; COLE, C.V. The potential of U.S. Cropland to sequester carbon and mitigate the greenhouse effect. Ann Arbor: Ann Arbor Press, 1998. 123p.

LEITE, L.F.C.; MENDONÇA, E.S.; MACHADO, P.L.O.A. Simulação pelo modelo Century da dinâmica da matéria orgânica de um Argissolo sob adubação mineral e orgânica. Revista Brasileira de Ciência do Solo, v.28, p.347-358, 2004.

LIMA, V.C.; LIMA, J.M.C.; EDUARDO, B.J.P.; CERRI, C.C. Conteúdo de carbono e biomassa microbiana em agrosistemas: comparação entre métodos de preparo do solo. Revista do Setor de Ciências Agrárias, v.13, p.297-302, 1994

LUCA, E.F. Matéria orgânica e atributos do solo em sistemas de colheita com e sem queima da cana-de-açúcar. Piracicaba: USP/CENA, 2002. 101p. Thesis (Ph.D.)

MACEDO, I.C. Emissão de gases do efeito estufa e a produção/ utilização de etanol da cana-de-açúcar no Brasil. Piracicaba: Centro de Tecnologia Copersucar, 1997. (Relatório Interno CTC05/97).

MACEDO, I.C. Greenhouse gas emissions and energy balances in bioethanol production and utilization in Brazil. Biomass and Bioenergy, v.14, p.77-81, 1998 .

MACHADO, P.L.O.A.; SILVA, C.A. Soil management under no-tillage systems in the tropics with special reference to Brazil. Nutrient Cycling in Agroecosystems, v.61, p.119-130, 2001.

METHERELL, A.K.; HARDING, L.A.; COLE, C.V; PARTON, W.J. CENTURY Soil organic matter model environment. Technical documentation. Agroecosystem version 4.0. Fort Collins: USDAARS, 1993. 201p. (Great Plains System Research Unit Technical Report, 4).

MILLENNIUM ECOSYSTEM ASSESSMENT. Ecosystems and human well-being: General Synthesis. Washington: Island Press, 2005. 765p

MITCHELL, T.D.; CARTER, T.R.; JONES, P.D.; HULME, M.; NEW, M. A comprehensive set of high-resolution grids of monthly climate for Europe and the globe: the observed record (1901-2000) and 16 scenarios (2001-2100). Norwick: Tyndall Centre, 2004. (Working Paper, 55).

MORAES, J.F.L.; CERRI, C.C.; MELILLO, J.M.; KICKLIGHTER, D.; NEILL, C.; SKOLE, D.; STEUDLER, P.A. Soil carbon stocks of the Brazilian Amazon basin. Soil Science Society of America Journal, v.59, p.244-247, 1995.

NEILL, C.; CERRI, C.C.; MELILLO, J.; FEIGL, B.J.; STEUDLER, P.A.; MORAES, J.F.L.; PICCOLO, M.C. Stocks and dynamics of soil carbon following deforestation for pasture in Rondonia. In: LAL, R.; KIMBLE, J.M.; FOLLETT, R.F.; STEWART, B.A., (Ed.) Soil processes and the carbon cycle. Boca Raton: CRC Press, 1997. p.9-28.

OLIVEIRA, M.E.D.; VAUGHAN, B.E.; RYKIEL JR., E.J. Ethanol as fuel: energy, carbon dioxide balances, and ecological footprint. BioScience, v.55, p.593-602, 2005.

OVERPECK, J.T.; COLE, J.E. Abrupt change in Earth's climate system. Annual Review of Environment and Resources, v.31, p.1$31,2006$.
PARTON, W.J.; SCHIMEL, D.S.; COLE, C.V.; OJIMA, D.S. Analysis of factors controlling soil organic matter levels in Great Plains grasslands. Soil Science Society of America Journal, v.51, p.1173$1179,1987$.

PAUSTIAN, K.; LEVINE, E.; POST, W.M.; RYZHOVA, I.M. The use of models to integrate information and understanding of soil $\mathrm{C}$ at the regional scale. Geoderma, v.79, p.227-260, 1997.

PAUSTIAN, K.; SIX, J.; ELLIOTT, E.T.; HUNT, H.W. Management options for reducing $\mathrm{CO}_{2}$ emissions form agricultural soils. Biogeochemistry, v.48, p.147-163, 2000

PAVEI, M.A. Decomposição de resíduos culturais e emissão de gases de efeito estufa em sistemas de manejo do solo em Ponta Grossa (PR). Piracicaba: USP/ECOAGROEC, 2005. 114p. Thesis (Master).

PLATAFORMA PLANTIO DIRETO. Sistema Plantion Direto 2006. Available in: 〈http://www.embrapa.br/plantiodireto>. Accessed in: 11 dec. 2006.

PEIXOTO, R.T.; STELLA, L.M.; MACHULEK JUNIOR, A.; MEHL, H.U.; BATISTA, E.A. Distibução das frações granulométricas da matéria orgânica em função do manejo do sols. In: ENCONTRO BRASILEIRO SOBRE SUBSTÂNCIAS HÚMICAS, 3., Santa Maria, 1999. Proceedings. Santa Maria, 1999. p.346-348.

PERRIN, A.S. Effets de différents modes de gestion des terres agricoles sur la matière organique et la biomasse microbienne en zone tropicale humide au Brésil. Lausanne: Ecole Polytechnique Fédérale de Lausanne., 2003. 68p. Thesis (M.Sc.).

POLWSON, D.S. Will soil amplify climate change? Nature, v.433, p.204-205, 2005.

PRITCHARD, S.G.; AMTHOR, J.S. Crops and environmental change: an introduction to effects of global warming, increasing atmospheric $\mathrm{CO}_{2}$ and $\mathrm{O}_{3}$ concentrations, and soil salinization on crop physiology and yield. New York: Food Products Press, 2005. 368p.

REICOSKY, D.C.; KEMPER, W.D.; LANGDALE, G.W.; DOUGLAS, C.L.; RASMUNSSEN, P.E. Soil organic matter changes resulting from tillage and biomass production. Journal of Soil \& Water Conservation, v.50, p.253-261, 1995.

RESCK, D.V.S.; VASCONCELLOS, C.A.; VILELA, L.; MACEDO, M.C.M. Impact of conversion of brazilian Cerrados to cropland and pastureland on soil carbon pool and dynamics. In: LAL, R.; KIMBLE, J.M.; STEWART, B.A., (Ed.). Global climate change and tropical ecosystems. Boca Raton: CRC Press, 2000. p.169-196.

RIEZEBOS, H.T.H.; LOERTS, A.C. Influence of land use change and tillage practice on soil organic matter in southern Brazil and eastern Paraguay. Soil \& Tillage Research, v.49, p.271-275, 1998.

RIPOLI, T.C.; MOLINA JR., W.F.; RIPOLI, M.L.C. Energy potential of sugar cane biomass in Brazil. Scientia Agricola, v.57, p.677-681, 2000.

ROSCOE, R.; BUURMAN, P. Tillage effects on soil organic matter in density fractions of a Cerrado Oxisol, Soil \& Tillage Research, v.70, p.107-119, 2003.

RUDDIMAN, W.F. How did humans first alter global climate? Scientific American, v.292, p.34-41, 2005.

SA, J.C.M. Dinâmica da matéria orgânica do solo em sistemas de manejo convencional e plantio direto no estado do Paraná. Piracicaba: USP/ ESALQ, 2001. 114p. Thesis (Ph.D.).

SA, J.C.M.; CERRI, C.C.; LAL, R.; DICK, W.A.; VENZKE FILHO, S.; PICCOLO, M.C.; FEIGL, B. Organic matter dynamics and carbon sequestration rates for a tillage chronosequence in a Brazilian Oxisol. Soil Science Society of America Journal, v.65, p.1486-1499, 2001.

SCHUMAN, G.E.; JANZEN, H.H.; HERRICK, J.E. Soil carbon dynamics and potential carbon sequestration by rangelands. Environmental Pollution, v.116, p.391-396, 2002.

SCOPEL, E.; DOUCENE, E.; PRIMOT, S.; DOUZET, J.M.; CARDOSO, A.; FELLER, C. Diversity of direct seeding mulch based cropping systems (DMC) in the Rio Verde region (Goias, Brazil) and consequences on soil carbon stocks. In: WORLD CONGRESS ON CONSERVATION AGRICULTURE, 2., Foz do Iguaçú, 2003. Proceedings. Foz do Iguaçu, 2003. p.286-289.

SILVA, G.M.A. Cana crua x cana queimada: restrições técnicas e implicações sociais e econômicas. In: SECAPI, 1., Piracicaba, 1997. Proceedings. Piracicaba, 1997. p.55-57. 
SILVA, A.L.; ROVERATTI, R.; REICHARDT, K.; BACCHI, O.O.S.; TIMM, L.C.; BRUNO, I.P.; OLIVEIRA, J.C.M.; DOURADO NETO, D. Variability of water balance components in a coffee crop in Brazil. Scientia Agricola, v.63, p.105-114, 2006.

SIMÕES, M.S.; ROCHA, J.V.; LAMPARELLI, R.A.C. Spectral variables, growth analysis and yield of sugarcane. Scientia Agricola, v.62, p.199-207, 2005.

SIQUEIRA, O.J.F.; FARIAS, J.R.B.; SANS, L.M.A. Potential effects of global climate change for Brazilian agriculture and adaptative strategies for wheat, maize and soybean. Revista Brasileira de Agrometeorologia, v.2, p.115-129, 1994.

SIQUEIRA, O.J.F.; STEINMETZ, W.S.; SALLES, L.A.B.; FERNANDES, J.M. Efeitos potenciais das mudanças climáticas na agricultura brasileira e estratégias adaptativas para algumas culturas. In: MUDANÇAS CLIMÁTICAS GLOBAIS E A AGROPECUÁRIA BRASILEIRA, 1., Jaguariúna, 2001. Proceedings. Jaguariúna: Embrapa Meio Ambiente, 2001. p.33-64.

SIQUEIRA NETO, M. Estoques de carbono e nitrogênio do solo e emissões de gases do efeito estufa no sistema plantio direto em Tibagi (PR). Piracicaba: USP/ESALQ, 2003. 78p. Thesis (Master).

SISTI, C.P.J.; DOS SANTOS, H.P.; KOHHANN, R.; ALVES, B.J.R.; URQUIAGA, S.; BODDEY, R.M. Change in carbon and nitrogen stocks in soil under 13 years of conventional or zero tillage in southern Brazil, Soil \& Tillage Research, v.76, p.39-58, 2004.

SIVAKUMAR, M.V.K.; DAS, H.P. Impacts of present and future climate variability on agriculture and forestry in the arid and semi arids tropcs. Climatic Change, v.70, p.31-72, 2005.

SIX, J.; ELLIOTT, E.T.; PAUSTIAN, K. Aggregate and soil organic matter dynamics under conventional and no-tillage systems. Soil Science Society of America Journal, v.63, p.1350-1358, 1999.

SIX, J.; FELLER, C.; DENEF, K.; OGLE, S.M.; SA, J.C.M.; ALBRECHT, A. Soil organic matter, biota and aggregation in temperate and tropical soils - effects of no-tillage. Agronomie, v.22, p.755-775, 2002.

SMITH, P.; POWLSON, D.S.; GLENDINING, M.J.; SMITH, J.U. Preliminary estimates of the potential for carbon mitigation in European soils through no-till farming. Global Change Biology, v.4, p.679-685, 1998.

SOARES, J.L.N.; ESPINDOLA, C.R.; PEREIRA, W.L.M. Physical properties of soils under intensive agricultural management. Scientia Agricola, v.62, p.165-172, 2005.
SOCIEDADE NACIONAL DE AGRICULTURA. Brasil, açúcar e álcool: Cronologia da cana no Brasil. Rio de Janeiro, 2002. Available in: 〈http://www.snagricultura.org.br〉. Accessed in: 20 nov. 2002.

SPAGNOLLO, E.; BAYER, C.; PRADO WILDNER, L.; ERNANI, P.R.; ALBUQUERQUE, J.A.; PROENÇA, M.M. Influência de plantas intercalare ao milho no rendimento de grãos e propriedades químicas do sols em differentes sistemas de cultivo. In: ENCONTRO BRASILEIRO SOBRE SUBSTÂNCIAS HÚMICAS, 3., Santa Maria, 1999. Proceedings. Santa Maria, 1999. p.229-231.

TESTA, V.M.; TEIXEIRA, L.A.J.; MIELNICZUK, J. Características químicas de um podzólico vermelho escuro afetada por sistemas de culturas, Revista Brasileira de Ciência do Solo, v.16, p.107-114, 1992.

THORBURN, P.J.; PROBERT, M.E.; ROBERTSON, F.A. Modelling decomposition of sugar cane surface residues with APSIM-Residue. Field Crops Research, v.70, p.223-232, 2001.

TRUMBORE, S.E.; DAVIDSON, E.A.; CAMARGO, P.B.; NEPSTAD, D.A.; MARTINELLI, L.A. Below-ground cycling of carbon in forest and pastures of eastern Amazonia. Global Biogeochemical Cycles, v.9, p.515-528, 1995.

UNFCCC. National Reports. United Nations Frameworks Convention on Climate Change. Bonn, 2006. Available in: <http://unfccc.int/ national_reports/items/1408.php>. Accessed in: 20 oct. 2006.

VASCONCELLOS, C.A.; FIGUEIREDO, A.P.M.; FRANÇA, G.E.; COELHO, A.M.; BRESSAN, W. Manejo do sols e a atividade microbiana em latossolo vermelho-escuro da região de Sete Lagoas, MG. Pesquisa Agropecuaria Brasileira, v.33, p.1897-1905, 1998.

VENZKE FILHO, S.P.; SIQUEIRA NETO, M.; PICCOLO, M.C.; FEIGL, J.; CERRI, C.C. Características químicas do solo em função do tempo de adoção do sistema plantio direto. In: FERTIBIO 2002. Rio de Janeiro, 2002. Agricultura: Bases ecológicas Para o desenvolvimento social e econômico sustentado. Seropédica : UFRRJ, Depto Solos, 2002..

ZOTARELLI, L.; ALVES, B.J.R.; URQUIAGA, S.; TORRES, E.; PAUSTIAN, K.; BODDEY, R.M.; SIX, J. Efeito do preparo do solo nos agregados do solo e no conteúdo de matéria orgânica. In: CONGRESSO BRASILEIRO DE CIÊNCIA DO SOLO, 34., Ribeirão Preto, 2003. Proceedings. Ribeirão Preto, 2003.

Received January 02, 2007

Accepted January 20, 2007 